\title{
THE EMERGENCY PRICE CONTROL ACT OF 1942: BASIC AUTHORITY AND SANCTIONS **
}

\author{
David Ginsburg $\dagger$
}

\section{INTRODUCTION}

Every comprehensive regulatory statute is, in a sense, an experiment in practical government. No legislative draftsman, however careful and informed, can determine in advance a statute's working adequacy. The statute itself is but a tool for the accomplishment of desired public ends, and its worth as a tool must be judged in and by experience. ${ }^{1}$

The most significant fact about the Emergency Price Control Act of 1942 is that the essential techniques of control which it embodies were developed and tried in actual experience. For more than a year before the introduction of the original price control bill, the Price Stabilization Division and the Office of Price Administration and Civilian Supply had been studying, and wrestling with, the hard price problem. Price action under executive authority continued throughout the six months during which the bill was pending before the Congress.

The lessons of that experience are now part of the Act. The wisdom of selective price control for a period when the country was just mustering its industrial forces, and the usefulness of base period prices in maximum price determinations, were proven in pre-statutory practice. The necessity for industry consultation, and the value of voluntary agreements, and of explanatory statements to accompany price

* The provisions of the Act authorizing the fixing of maximum rents for defense-area housing accommodations are dealt with in Borders, Emergency Rent Control, infra. The provisions relating to the issuance, protest, and review of regulations under the Act are discussed in Nathanson, The Emergency Price Control Act of 1942: Administrative Procedure and Judicial Review, infra at 60. ED.

†B.A., 1932, West Virginia University; LL.B., 1935, Harvard University. General Counsel, Office of Price Administration. Attorney, Securities and Exchange Commission, 1935-r939; law clerk to Mr. Justice Douglas, 1940; General Counsel, Price Stabilization Division, National Defense Advisory Commission; General Counsel, Office of Price Administration and Civilian Supply.

The author is deeply indebted for assistance in the preparation of this article to his colleagues on the legal staff of the Office of Price Administration.

1 This incidentally suggests the danger of trying to explain the meaning of particular language in the unique provisions of a law as broad and as flexible as this one, apart from the facts of a particular case, and even before that language has been interpreted in day-to-day operations in any case. It cannot be done. Although the interpretative opinions set forth in this article have been tentatively accepted by at least a few members of the staff, all of them have not yet been considered with the Administrator, and some of them are almost certain to be changed as new considerations are brought to bear on particular points. These interpretative opinions, therefore, will not be regarded as binding on the Office of Price Administration. 
regulations became evident in the course of price action. The importance of the buying and selling powers was demonstrated by the pre-statutory use of that technique in connection with control of the supply and price of copper, rubber, wool, and numerous other stockpiled commodities. ${ }^{2}$ Any fair evaluation of the pre-statutory activities of the Office of Price Administration and its predecessor agencies must be based upon full recognition that throughout that period those charged with responsibility for price stabilization were not only fighting a delaying action against inflation but were also sharpening the administrative methods now written into law. As our military production approaches full tide it may be necessary drastically to expand the field of price control, but individual price regulations, formulated in terms of base period prices appropriately adjusted, will undoubtedly remain keystones in the structure of price control, whatever form that structure ultimately may take.

To understand the essential continuity in the evolution of the price control program it is necessary to consider the successive stages of price stabilization authority. Consideration was given to the price problem from the outset of the defense effort shortly after the fall of France. On May 29, I940, President Roosevelt established an Advisory Commission to the Council for National Defense and set up in the Advisory Commission a Price Stabilization Division, charged with a general responsibility for price stability. 3 The Price Stabilization Division, for a time, devoted its attention principally to close study and investigation of significant supply and price trends, stressing the expansion of supply as the best means of price stabilization. The results of the Division's studies and investigations were often made public, and, in many instances, announcement that no actual shortage existed, or that threatened price rises were speculative in character, was sufficient to stabilize important markets.

The unfolding of Axis strategy and the acceleration of the American defense effort soon created a condition of acute shortage in a number of essential commodities. More direct price action became imperative. The first price schedule was issued by the Price Stabilization Division on February I7, I94I, and announced a ceiling for second-hand machine tool prices, which had risen to fantastic heights. Five price schedules, in all, were issued by the Price Stabilization Division. ${ }^{4}$ Although no direct and effective sanctions were available to secure observance of these schedules, the force of public opinion was sufficient to give them substantial effect.

\footnotetext{
${ }^{2}$ The procedure by which the copper problem was handled by cooperation between OPA and RFC was outlined by Leon Henderson before the Senate Committee on Banking and Currency. Hearings before the Senate Committee on Banking and Currency on H. R. 5990, 77th Cong., Ist Sess. (194I) (hereinafter referred to as "Senate Hearings") I06 et seq.

${ }^{3}$ See Memorandum, "The Activities of the Price Stabilization Division and the Office of Price Administration and Civilian Supply," Hearings before the House Committee on Banking and Currency on H. $R$. 5479, superseded by H. R. 5990, 77th Cong., Ist Sess. (I94I) (hereinafter referred to as "House Hearings") 277.

No. 2, aluminum scrap and secondary aluminum ingot, March 24, 194r; No. 3, zinc scrap materials and sccondary slab zinc, March 31, 194I; No. 4, iron and steel scrap, April 2, r94I; No. 5, bituminous coal, April 2, 1941. On April 15, 194I, the Administrator of OPACS adopted the price schedules of the Price Stabilization Division. See Memorandum, "The Present Price Control Authority of the President and the Office of Price Administration and Civilian Supply," House Hearings 373, 374.
} 
On April II, I94I, the President issued Executive Order No. 8734,5 which established the Office of Price Administration and Civilian Supply and authorized the Administrator of that Office to:

2(a) Take all lawful steps necessary or appropriate in order ( $I$ ) to prevent price spiraling, rising costs of living, profiteering, and inflation. . . .

(c) Determine and publish, after proper investigation, such maximum prices, commissions, margins, fees, charges, or other elements of cost or price of materials or commodities, as the Administrator may from time to time deem fair and reasonable; and take all lawful and appropriate steps to facilitate their observance.

Executive Order No. $8875,{ }^{6}$ issued by the President on August 28, 1941, lodged the civilian allocation functions earlier vested in the Office of Price Administration and Civilian Supply in the Office of Production Management, but the price control authority conferred by Executive Order No. 8734 was continued in the Office of Price Administration, the successor to the Office of Price Administration and Civilian Supply. The scope of price action was greatly broadened and, as new industries were brought under price regulation, the need for direct sanctions to secure the observance of price schedules was increasingly felt. ${ }^{7}$

Meanwhile, on July 30, I94I, the President had sent to the Congress a vigorous message, ${ }^{8}$ calling attention to the existing threat of inflation and recommending the immediate adoption of legislation giving the Office of Price Administration adequate powers to establish and to enforce maximum price and rent regulations. Two days later the original price control bill ${ }^{9}$ was introduced in both Houses of the Congress. The bill was before the Congress for six months, the hearings of the House Committee on Banking and Currency alone lasting until the end of October. ${ }^{10}$ After three more months of heated Congressional controversy, in which the bill narrowly escaped emasculation by the House of Representatives, ${ }^{11}$ the Emergency Price Control Act ${ }^{12}$ became law on January 30, 1942.

\footnotetext{
86 FED. REG. I9I7 (194I). ${ }^{\circ} I d .4483$.
}

TThe sanctions available under Executive Orders Nos. 8734 and 8875 are indirect and cumbersome. Par. 2(h) of Executive Order No. 8734 empowers the Administrator to recommend to the President the exercise of such of his powers as the commandeering power, Selective Service Act, \$9, 54 \$TAT. 892 (1940), 50 U. S. C. A. $\$ 309$ (Supp. I94I), and the priority power, Priorities Act, \$2(a), 54 STAT. 676 (1940), as amended by the Vinson Act, Pub. L. No. 89, 77th Cong., 1st Sess. (May 31, 1941), when in the judgment of the Administrator such action by the President would enforce compliance with price schedules.

${ }^{8}$ H. R. Doc. No. 332, 77th Cong., Ist Sess. (1941), reprinted in Hottse Hearings 2-4.

${ }^{\circ}$ H. R. 5479, S. 1810, 77th Cong., Ist Sess. (Aug. 1,1941 ).

${ }^{10}$ The printed House Hearings run to a total of 2,305 pages.

11 The House Committee substituted for H. R. 5479 a modified bill, H. R. 5990, which adopted the original procedural and judicial review provisions but made such changes as omission of the licensing and treble damage sanctions and the restriction of buying and selling powers. Sec H. R. REp. No. I409 (hereinafter called "House Report"). After four days of debate, 87 Cong. Rec., Nov. 24-28, 1941, at 9297-9326, 9333-9378, 9383-94 $18,9436-9483$, the House passed a price control bill quite different from that recommended by its Committee and wholly inadequate for the job of emergency price control. For example, every action of the Administrator was subject to complete re-examination and revision by a Board of Administrative Review.

The essential provisions omitted by the House Committee, or stricken on the House floor, were reinstated by the Senate Committee on Banking and Currency, after it had invited OPA representatives to submit recommended changes in the House Bill. Senate Hearings 72-r05. Substantially as reported by 
The transition from price action under executive authority to price action under Congressional authorization was effected with no break in the continuity of the price program. Leon Henderson, who had headed the three pre-statutory price agencies, was appointed Price Administrator under the Act and took office on February II. In accordance with the express provisions of Section 206 of the Act, ${ }^{13}$ price schedules issued by the Office of Price Administration and Civilian Supply and the Office of Price Administration prior to February $x x$, were re-examined, revised, and substantially all of them continued in effect, as if issued under the authority of the Act. ${ }^{14}$ In fact, since the basic techniques of control embodied in the Act were those which had been developed in pre-statutory experience, the Office of Price Administration was able to continue its essential administrative operations without substantial change.

But times and values have changed markedly since the form of the statute was finally determined. In the fall of I94I, although death and destruction destined for this country were already being loaded into Axis bomb-racks, the Government was forced to compromise its necessity, and cautiously clothe that compromise in the peace-time habiliments of administrative law. This was necessary to secure price control legislation of any kind. Will that compromise suffice for war?

To this question there is no single unqualified answer. Appropriations are needed to recruit a competent staff and to establish numerous offices in the field.15 Hostile forces may seek to limit those appropriations and thus hamstring successful administration. Living quarters and office space must be provided to house the staff. Washington is a crowded place, yet decentralization before policy has been determined is extremely difficult and dangerous. Moreover, the task of price control is after all a limited one; alone it cannot succeed in preventing a disastrous inflation. Other agencies responsible for the supply and flow of goods and for the Government's labor, fiscal and monetary policies must share the responsibility and the burden. The growing volume of excess purchasing power must be reduced. Widespread

the Committee, SEN. ReP. No. 93I, 77th Cong., 2d Sess. (1942) (hereinafter called "Senate Report"), the bill passed the Senate after four days of debate, 88 Cong. Rec., Jan. 7-10, 1942, at 68-90, 99-136, I65I94, 217-252, and was referred to Conference Committee. The Conference Committee adopted essentially the Senate bill. H. R. Rep. No. 1658 (hereinafter called "Conference Report"). The recommendations of the Conference Committee were adopted by the House on January 26, after a motion to recommit had been defeated by only 2 Io to 189,88 Cong. Rec., Jan. 26 , 1942, at 7I0-7II, and passed the Senate on Jan. 27 by an overwhelming rote. Id. at 750 .

${ }_{12}$ Pub. L. No. 42I, 77th Cong., 2d Sess. (1942).

13 'SEc. 206. Any price schedule establishing a maximum price or maximum prices, issued by the Administrator of the Office of Price Administration or the Administrator of the Office of Price Administration and Civilian Supply, prior to the date upon which the Administrator provided for by section 201 of this Act takes office, shall, from such date, have the same effect as if issued under section 2 of this Act until such price schedule is superseded by action taken pursuant to such section 2. Such price schedules shall be consistent with the standards contained in section 2 and the limitations contained in section 3 of this Act, and shall be subject to protest and review as provided in section 203 and section 204 of this Act. All such price schedules shall be reprinted in the Federal Register within ten days after the date upon which such Administrator takes office."

${ }^{14}$ As required by $\$ 206$, these price schedules (IOI of the 105 originally issued) were reprinted in the Federal Register on Feb. 2I, 1942. 7 FED. REG. 1202-1406.

${ }^{15}$ Regional offices have been established in Atlanta, Baltimore, Boston, Chicago, Cleveland, Dallas, Denver, Kansas City, Mo., New York, Philadelphia, and San Francisco. 
rationing of consumer goods and perhaps incomes must be undertaken. Assuming, however, a willingness on the part of the Congress to back effective price control, and the existence of a sound complementary executive policy, the law, notwithstanding its limitations, is probably strong enough and flexible enough to carry out its mission in the war against inflation. But that war-and perhaps another-will not be won unless we strike boldly and swiftly on all fronts now.

\section{Commodity Prices}

The price control contemplated by the Act is control over the maximum prices of all articles, products, and materials, whether raw materials, foodstuffs, or finished products, and whether at the manufacturer's, wholesaler's, or retailer's level..$^{10}$ This authority extends over exports and imports and over sales and purchases by the United States and the states, or any agencies or subdivisions of either. ${ }^{17}$ But the Act does not become effective except through regulations or orders issued by the Administrator. No matter how carefully considered or artistically phrased, no single statutory rule would be adequate to meet the myriad contingencies of all-inclusive price control..$^{18}$ As will appear, the Administrator is left free to make full use of differing formulae and techniques in determining, with respect to each commodity, a maximum price that is generally fair and equitable and which will accomplish the purposes of the legislation.

Section 2(a) of the Act contains the basic grant of authority to control commodity prices. ${ }^{19}$ The Administrator may act whenever, in his judgment, the price or prices

${ }^{20}$ Exempt from the coverage of the Act are wages and salaries; professional fees; public utility rates; insurance rates; rates charged by persons engaged in operating or publishing newspapers, periodicals, or magazines, or in operating radio broadcasting stations, motion picture or other theatcr enterpriscs, or outdoor advertising facilities. Exempt, also, are materials furnished for publication by any press association or feature service, and books. But included are services rendered otherwise than as an employec in connection with the processing, distribution, storage, installation, repair, or negotiation of purchases or sales, of a commodity, or in connection with the operation of any service establishment for the servicing of a commodity. $\$ 302$ (c). Cf. $\$ 205(\mathrm{f})(\mathrm{I})$, establishing certain exemptions from the licensing provisions of the Act.

12 "The term 'person' . . includes the United States or any agency thereof, or any other government, or any of its political subdivisions, or any agency of any of the foregoing." $\$ 302(\mathrm{~h})$.

${ }^{18}$ The three thousand pages of Senate and House Hearings constitute perhaps the best treatise extant on the problems of price control. See particularly House Hearings 237-301.

${ }^{10}$ Section $2(a)$ is in part as follows: "Whenever in the judgment of the Price Administrator (provided for in Section 201) the price or prices of a commodity or commodities have risen or threaten to rise to an extent or in a manner inconsistent with the purposes of this Act, he may by regulation or order establish such maximum price or maximum prices as in his judgment will be generally fair and equitable and will effectuate the purposes of this Act. So far as practicable, in establishing any maximum price, the Administrator shall ascertain and give due consideration to the prices prevailing between October $I$ and October 15, 1941 (or if, in the case of any commodity, there are no prevailing prices between such dates, or the prevailing prices between such dates are not generally representative because of abnormal or seasonal market conditions or other cause, then to the prices prevailing during the nearest two-week period in which, in the judgment of the Administrator, the prices for such commodity are gencrally representative), for the commodity or commodities included under such regulation or order, and shall make adjustments for such relevant factors as he may determine and deem to be of general applicability, including the following: Speculative fluctuations, general increases or decreases in costs of production, distribution, and transportation, and general increases or decreases in profits earned by sellers of the commodity or commodities, during and subsequent to the year ended October I, I94I. Every regulation or order issued under the foregoing provisions of this subsection shall be accompanied by a statement of the considerations involved in the issuance of such regulation or order." 
of a commodity or commodities have risen or threaten to rise to an extent or in a manner inconsistent with the purposes of the Act. In such a case he may, by regulation or order, establish such maximum price or maximum prices as in his judgment will be generally fair and equitable and will effectuate the purposes of the Act. Discretion is thus lodged in the Administrator either to establish maximum prices for particular commodities or groups of commodities in furtherance of a policy of selective price control or, if it should prove necessary, to establish a ceiling over prices for all or a number of commodities at one time. ${ }^{20}$

The basic standards that must be satisfied under the Act in establishing maximum prices are that the prices must be generally fair and equitable ${ }^{21}$ and must effectuate the purposes of the Act. ${ }^{22}$ The outer contours of the term "generally fair and equitable" are not susceptible of precise definition, and its content will vary with the particular commodity. Certain questions are immediately raised: May prices be generally fair and equitable which are nevertheless too low to permit a particular producer or seller to sell the commodity profitably? The answer to the question as so stated clearly must be in the affirmative. ${ }^{23}$ Maximum price regulations are quasilegislative enactments of general applicability; their fairness must be general and not specific, and the Act expressly so provides. ${ }^{24}$ But what is meant by the term "gen-

${ }^{20}$ In the House there was much controversy over the respective merits of the "Baruch Plan," contemplating an "over-all ceiling" covering all commodity prices, rents, interest rates, wages, salaries and profits, as of a base date, on the one hand, and of selective price control on the other. Testimony of Bernard M. Baruch, House Hearings 989-1045. The "Baruch Plan" was partially embodied in a series of bills introduced by Congressman Albert Gore, H. R. 5760, H. R. 5997, H. R. 6086, 77th Cong., Ist Sess. (194I), but was defeated on the floor by a vote of 218 to 63 . 87 Cong. Rec., Nov. 26, 194I, at 9410. The Act is nevertheless sufficiently flexible to authorize a general ceiling technique for commodity prices (exclusive, therefore, of profits, wages and salaries, and rents in non-defense areas), should it seem appropriate to do so.

${ }^{31}$ The bill as introduced required that established maximum prices be generally fair and equitable to buyers and sellers, and effectuate the purposes of the Act. H. R. 5479, 77th Cong., Ist Sess. (I94I), $\$ 2(a)$. The italicized language was omitted from H. R. 5990, as reported by the House Banking and Currency Committee. The omission was to make clear that the general fairness and equity of "ceilings," was not to be measured by purely private considerations.

${ }^{22}$ Section I (a) provides: "It is hereby declared to be in the interest of the national defense and security and necessary to the effective prosecution of the present war, and the purposes of this Act are, to stabilize prices and to prevent speculative, unwarranted, and abnormal increases in prices and rents; to eliminate and prevent profiteering, hoarding, manipulation, speculation, and other disruptive practices resulting from abnormal market conditions or scarcities caused by or contributing to the national emergency; to assure that defense appropriations are not dissipated by excessive prices; to protect persons with relatively fixed and limited incomes, consumers, wage earners, investors, and persons dependent on life insurance, annuities, and pensions, from undue impairment of their standard of living; to prevent hardships to persons engaged in business, to schools, universities, and other institutions, and to the Federal, State, and local governments, which would result from abnormal increases in prices; to assist in securing adequate production of commodities and facilities; to prevent a post emergency collapse of values; to stabilize agricultural prices in the manner provided in section 3; and to permit voluntary cooperation between the Government and producers, processors, and others to accomplish the aforesaid purposes."

33 "Because of the legislative nature of regulations establishing maximum prices, applying to large numbers of sellers, the bill does not guarantee a profit to each individual seller." Senate Report 15.

It was consistently recognized that high cost producers might require special treatment through a differential pricing system, in many cases accompanied by purchases pursuant to \$2(e). House Hearings $319-320,401-403,467-468,652-653$. However, there is nothing in the legislative history to suggest that such a system or purchases are required merely because the maximum price is too low to permit high cost sellers to continue to sell the particular commodities at a profit.

${ }^{24}$ Such a result would not be open to successful challenge under the Fifth Amendment. Morrisdale 
erally?" To what percentage of the sellers of a particular commodity must the regulation be fair and equitable-a majority? the bulk? 95 percent? And does the term "generally" have reference to numbers of sellers or to volume of sales?"5

To raise these questions is but again to state that a single definitive answer is impossible. Certain frames of reference may be formulated against which the consequences of a maximum price can be measured. But a frame of reference is not a mold to which the maximum price must be shaped. Frames of reference and, indeed, the content of the term "generally fair and equitable," will change not only with the commodity but with the economic level at which price control is being exercised. To think and to speak in terms of a price that is generally fair and equitable to producers responsible for the bulk of the production may be entirely appropriate in measuring the effect of maximum prices established at the manufacturing level. Yet the concept may carry no particular meaning when, for example, the consequences of a general price ceiling over all or most prices at the retail level are being appraised in the light of the statutory standards.

Certain specific guides to what is generally fair and equitable for individual prices are indicated by Section 2(a). But these are not exclusive, and need be applied only "so far as practicable." Moreover, there is much room for judgment in the application of even those guides that are specified. This can perhaps best be illustrated by raising certain of the administrative and operating problems inherent in the application of the deceptively simple language of Section 2(a). In their essence, none of these problems is susceptible of decisive solution by the Administrator or the courts. They merely suggest the existence of several courses of action, any of which may be reasonable. Tentative administrative choices will unquestionably be reconsidered in the light and as a result of experience gained in day-to-day operations. ${ }^{20}$

In issuing a maximum price regulation, the Administrator is required, so far as practicable, to ascertain and give due consideration to the prices prevailing between October I and October 15, I94I. ${ }^{27}$ If there were no prevailing prices for the particular

Coal Co. v. U. S., 259 U. S. 188 (1922) (Lever Act); Highland v. Russell Car Co., 279 U. S. 253 (1929) (Lever Act); DuPont de Nemours \& Co. v. Hughes, 50 F. (2d) 82 I (C. C. A. 3d, r93I) (Lever Act); Hamilton v. Kentucky Distilleries Co., 25 I U. S. 146 (1919) (Prohibition Act); Ruppert v. Caffcy, 25I U. S. 264 (I920) (Prohibition Act); Legal Tender Cases, 12 Wall. 457, 55 I (U. S. I870). And sce Tagg Bros. \& Moorhead v. U. S., 29 F. (2d) 750, 755 (D. Neb. 1928), aff'd, 280 U. S. 420 (1930) (Packers and Stockyards Act of I92I).

${ }^{20}$ The Senate Report suggests an answer: The bill requires that "prices be generally fair and equitable as applied to the sellers responsible for the major part of the output of any commodity." Senate Report $\times 5$.

${ }^{20}$ The Administrator and his staff are in continuous touch with the persons affected by the regulations. These contacts are informal, through the medium of telephone calls, letters, and personal mectings, and semi-formal through reports and other information obtained under \$202, and voluntarily offered. In addition, invaluable information and suggestions will be acquired from Industry Advisory Committecs established in accordance with $\$ 2(a)$.

${ }^{27}$ The bill as introduced established July 29, 194I, as the base date. H. R. 5479, 77th Cong., Ist Sess. (I94I), \$2(a). When reported by the House Committee, the date was changed to Oct. r, 194r. H. R. 5990, 77th Cong., Ist Sess. (I94x), \$2(a). The October I-15 period was established by amendment on the floor of the House. 87 Cong. Rec., Nov. 28, I94I, at 944I-2. A minor interpretative question is presented as to the exact period meant by the words "between October I and October 15, 194I"; that is, whether there is intended a 13-day, I4-day, or 15-day period, and if a I4-day period, whether Oztober I or October I5 is included. Although the further provision of $\$ 2(a)$ requiring the use of "the nearest two-weck 
commodity during the October I-I5 period, or if the prevailing prices during that period were not generally representative, the Administrator is required to ascertain and give due consideration to the prices prevailing during the two-week period nearest October I-I5, I94I, in which, in his judgment, the prices for the commodity were generally representative. This latter provision is of principal importance in those cases in which prices prevailing during October I-I5 were seasonal, or reflected speculative activities or abnormal market conditions, induced, for example, by a sudden flurry of Army-Navy buying. ${ }^{28}$

Clearly, however, the Administrator is not required to adopt the price which prevailed for the commodity during the base period as the maximum price. ${ }^{29}$ Nor is a maximum price immune from attack simply because it is the price which prevailed during that period. So far as practicable, the Administrator is to adjust such prices for such factors as he determines to be of general applicability. Certain of these factors are indicated: speculative fluctuations, general increases or decreases in costs of production, distribution, and transportation, and general increases or decreases in profits earned by sellers of the commodity, during and subsequent to the year ended October I, I94I. The effect of the price on production or supply is also important in almost every case. Many of the most difficult questions under the Act arise out of the need to make these adjustments.

In determining what adjustments to make to the October I-I5 prices, the Administrator is required to consider general increases or decreases in costs and profits of sellers during and subsequent to the year ended October I, I94I. Whether such costs and profits have generally increased or decreased can be determined only by comparing them with costs and profits of sellers during some other period. Wisely enough, the Act does not require any particular period to be taken as the basis for comparison. In many cases profits earned during the $1936-39$ period will be the best basis for comparison with profits earned during and subsequent to the year ended October I, I94I. This is true partly because that period did not reflect defense expenditures, partly because it comprised both good and bad years under peace-time conditions, and partly because the period has been utilized for purposes of the excess profits tax. ${ }^{30}$ Business enterprises subject to maximum price regulations accordingly have already compiled much of the necessary statistical information about operations during that period.

It has also been suggested that the first quarter of the year beginning October I, I 940 , be taken as the base period, on the ground that only by a comparison with

period" in certain cases, without more, at least suggests a $\mathrm{r}_{4}$-day interval, it seems most likely that a 15-day or half-month period was intended.

${ }_{28}$ The provision was also probably intended initially to protect such commodities as burley tobacco and shad, which are not marketed on October $\mathrm{x}$, and for which no prices would accordingly prevail. 87 Cong. Rec., Nov. 28, 194I, at 9470. After being reported by the Senate Banking and Currency Committee, $\S_{3}$ (a) was amended with that in mind. 88 Cong. Rec., Jan. ro, r942, at 233-34. Section 2(i), relating to fishery commodities, was added in conference. Conference Report 23.

${ }^{30}$ The legislative history indicates that in many cases the October I-15 period will serve merely as a point of departure. House Report 5; Senate Report I4-15.

${ }^{\circ 0}$ Second Revenue Act of 1940,54 STat. 980, 26 U. S. C. A. $57 r_{3}$ (b) (Supp. 1941). 
profits earned at the beginning of the year can it be determined whether profits have generally increased or decreased during the year. Similarly, in accordance with this suggestion, whether profits earned subsequent to the year ended October r, 194r, generally increased or decreased would be determined by comparing such profits with profits earned during the first quarter of the year beginning October $x$, 1940. Still another suggestion is that the year beginning October I, I939, and ending October I, I940, be taken as the base period; this on the ground that only by comparison with profits earned during the year just preceding the year ended October $\mathrm{x}, \mathrm{x} 94 \mathrm{x}$, can it be determined whether profits earned during that year, taken as a whole, generally increased or decreased. However, it is questionable whether either of these suggested periods is of sufficient duration to be fairly representative.

It is necessary here to do no more than emphasize that the choice of a comparative period is not a matter of statutory interpretation; it is one of fair administration. Reasons that would impel the choice of the 1936-39 period for a particular commodity might well give way in the light of considerations applicable to another commodity. The controlling test must be the reasonableness of the judgment exercised in the light of all the circumstances. No particular maximum price is the only one that is generally fair and equitable and will effectuate the purposes of the Act. There will be a range of maximum prices which satisfy these standards. The statutory requirements are met so long as the Administrator has acted in accordance with law and has not acted arbitrarily or capriciously in the light of the circumstances prevailing at the time of action. Thus, although the prices prevailing during the October I-I5 period could be adjusted downward in many cases (because such prices may allow profits greatly exceeding those earned during any selected comparative period), it may prove undesirable to do so. In the interest of stabilization, the Administrator generally has attempted to fix maximum prices at the levels which prevailed during October I-15, I94I. Severe dislocations might otherwise be caused. But once prices are established at these levels, they may well be maintained in the face of cost increases unless it can be shown that profits no longer compare favorably with profits earned during the period chosen for comparative purposes.

There is still another problem inherent in the use of the seller's profits as one measure of the general fairness and equitableness of a maximum price regulation. What is meant by "profits?"31 Is the Administrator limited in his consideration of profits to those earned upon the particular commodity under regulation, or may he consider the profits of the seller from its over-all operation? The question is particularly acute in industries a part of whose facilities are being converted to wartime production: As conversion accelerates, the per-unit cost of the commodities produced by the seller for civilian consumption will necessarily increase, although the over-all profitability of the seller may likewise increase. Joint-cost products are

\footnotetext{
${ }^{81}$ There should at least be general agreement that by "profits" it is meant "profits before income and excess profits taxes." No system of price control can operate successfully if the fairness of the prices established under it is to be tested by a comparison of profits after war-time taxes with profits after peacetime taxes.
} 
found in many important industries. ${ }^{32}$ Allocation of costs among such products is largely a matter of arbitrary accounting convention, the validity of which is not demonstrable. $^{33}$ The same, to a lesser degree, is probably true of the allocation of indirect expenses to a particular commodity, by a company making many commodities. $^{34}$ Efforts by the Administrator, in such instances, to allocate costs to particular commodities produced by the same seller would result only in interminable investigations and delay and would, in many cases, go far beyond what sellers themselves have regarded as necessary in the operation of their own businesses.

Section 2(a) requires that a maximum price regulation (other than a temporary regulation) be accompanied by a statement of the considerations involved in its issuance. The Act establishes no particular form and requires no particular content for such a statement. It is intended primarily to enable persons subject to a maximum price regulation to know the basis upon which the Office of Price Administration has acted in the issuance of a maximum price regulation. In many cases evidential material will doubtless be included. Persons protesting the maximum price regulation will thus be enabled to narrow the issues raised by their protest. ${ }^{35}$ In addition, such statements will provide a basis for the public evaluation of the work of the Office of Price Administration. It may be anticipated that there will be a gradual evolution in the form and content of these statements as their functions become more clearly defined.

Section 2(a) also permits the issuance of temporary maximum price regulations, effective for no more than 60 days, which may freeze the prices prevailing for any commodity within five days prior to the date of the issuance of the regulation. In general, regulations of this kind are designed to permit the Administrator to meet emergency situations speedily. Hence, the standards applicable to maximum price regulations of indefinite duration are inapplicable here; nor need such temporary regulations be accompanied by statements of considerations. ${ }^{36}$ The danger in the five-day limitation is that prices may be raised before the five-day period in anticipation of the action taken. Often it requires several days to determine the impact of a price regulation before it is issued; in many cases it may be desirable to consult with

${ }^{33}$ E.g., chemicals, meat packing, petroleum. Thus, acetic acid, wood alcohol, and charcoal are jointcost products derived from wood; acetone and butyl alcohol are joint-cost products derived from molasses or corn; glycerine and soap are joint-cost products derived from fats and oils.

s3 "No accountant has been able to devise a method yielding by-product or joint-cost figures which does not embody a dominance of arbitrariness and guesswork." Hamilton, Cost as a Standard for Price (1937) ${ }_{4}$ LaW \& Contemp. Prob., 321, 328.

34 The Supreme Court has recently held that the accounting system of a taxpayer "though useful or necessary as a business aid, may not fit the different requirements when a State seeks to tax values created by business within its borders." Butler Bros. v. McColgan, 62 Sup. Ct. 701, 704, decided March 2, 1942.

ss "This statement will afford those subject to a maximum price regulation an adequate opportunity to know the basis for its adoption and, therefore, intelligently to formulate, in the form of protests as provided in section 203 (a) of the bill, any objections which they may have to such regulation." Senate Report 15. The problems involved in protests, appeals and judicial review are dealt with separately elsewhere in this issue. See Nathanson, The Emergency Price Control Act of 1942: Administrative Procedure and Judicial Review, infra at 60 .

so "Such regulations may be issued without regard to the standards set forth in the bill for the issuance of permanent regulations and without an accompanying statement of considerations." Senate Report i5. 
representative sellers. The trade, therefore, frequently learns of the proposal while it is still in the discussion stage-and on the basis of trade rumor raise prices unjustifiably. Under such circumstances, it may be expected that OPA will issue permanent regulations reducing the lawful maximum below the speculative price, and will establish maximum prices in accordance with the other standards of the Act. One of the first operating questions presented to the Office under this section was whether a temporary regulation may establish as a maximum price the price prevailing on any one of the five days prior to the issuance of the regulation. Although the legislative history is silent on this precise point, such a result would seem to be fully consistent with the language of the provision and the underlying practical considerations. ${ }^{37}$

Something has already been said about the need for differing administrative techniques, and for flexibility in the issuance of maximum price regulations affecting different commodities. Considerations that would be controlling when establishing maximum prices for copper at the manufacturing level may be of no moment when establishing maximum prices for automobiles at the retail level. There is a like necessity for flexibility in the treatment of persons subject to a single price regulation. This flexibility is afforded by Section 2 (c), which provides that any regulation or order may be established in such form and manner, may contain such classifications and differentials, and may provide for such adjustments and reasonable exceptions as in the judgment of the Administrator are necessary or proper in order to effectuate the purposes of the Act. This section should be read in conjunction with Section 302(i), which permits still further flexibility by providing that maximum prices may be formulated, as the case may be, in terms of prices, margins, commissions, fees, and other charges and allowances. Section 2 (c) thus contemplates, for example, that the regulation establishing a maximum price may provide for premiums or discounts from an established maximum price, depending on the quantity of the commodity purchased or sold, or on other conditions of sale, such as credit terms. Similarly, differentials may be established for different kinds, grades, or quantities of commodities. Maximum prices may be fixed in terms of delivered prices or of f.o.b. prices, or of a basing point system..$^{38}$

Section 2(a) requires that maximum price regulations or orders of indefinite duration must be of general applicability and effect. Accordingly, provision for exceptions will be formulated in general terms in a Section 2(a) regulation. Application of the general class exception to particular persons will be sought by a petition for exception or adjustment requesting that such persons be excepted in accordance with the terms

${ }^{37}$ Initially, the prices were to be those prevailing "on the date of issuance." 88 Cong. Rec., Jan. 10, 7942, at 249. The change was to permit the collection of the necessary information. The prices may be those prevailing either generally or in the individual establishment. Senate Report 15.

38 "Sec. 2 (c) of the bill provides for flexibility in the establishment of maximum price and rent, and other, regulations under the bill. It authorizes classifications, differentiations, adjustments, and reasonable exceptions which in the judgment of the Administration are necessary or proper to effectuate the purposes of the bill. For example, classifications and differentiations may be made in terms of quantity, quality, or character of the use contemplated by the purchaser, or in terms of delivered prices on the one hand and f.o.b. prices on the other, or other conditions of sale." Senate Report I7. 
of the general rule. ${ }^{39}$ If no such general class is established in the maximum price regulation at the time of its issuance, petitions for amendment may be filed seeking to have such a general exception established. ${ }^{40}$ If a petition for amendment is granted, an order will presumably be issued under Section $2(\mathrm{c})$, placing the petitioner within the general class. Thus, there is opportunity for the Administrator to make special provision for cases of hardship and for high-cost producers whose continued production is necessary to the war effort. The exception for high-cost producers may permit the sale at a higher than established maximum price to the Administrator or some other Government agency, or on the open market.

It is, of course, impossible to anticipate the many situations which will require special treatment under Section 2(c). It provides a ready technique, however, for the adaptation of general rules to an almost infinite number of possible variations.

\section{Quality Deterioration, Speculative and Manipulative Practices, and Hoarding}

Substantial price rises may occur in reality although maximum price regulations are issued under Section 2(a) and, as a result, the selling price apparently remains constant. True stability in prices requires that the relationship between the amount paid and the value received be maintained. Success in controlling what the purchaser pays without holding relatively constant the quality he receives is of limited value as an anti-inflationary device.

But there is no blinking the fact that some degradation of quality is almost bound to result. Nor is there very much that can be done about it, so long as the deterioration does not go so far as to limit or destroy utility. Because consumers tend to resist such concealed price rises, because some manufacturers take a pride in their product and are willing to absorb cost increases rather than impair quality, and because in the fields where deterioration is most likely to occur, operations are both profitable and competitive, the problem has so far given OPA relatively little concern. Nevertheless, power to combat this quality deterioration is essential to any price control program. It is provided by Sections $2(\mathrm{~g})^{41}$ and $2(\mathrm{~d}) .{ }^{42}$ These sections make express the authority otherwise necessarily implied in Section 2 (a) to regulate the manipulation of form or quality. ${ }^{43}$

\footnotetext{
${ }^{30}$ Rules 38-41, OPA Procedural Regulation No. r, 7 Fed. REg. 971 (1942).

${ }^{10}$ Rules 35-37, loc. cit., supra note 39.

41 "Regulations, orders and requirements under this Act may contain such provisions as the Administrator deems necessary to prevent the circumvention or evasion thereof." $\$ 2(\mathrm{~g})$.

General procedural regulations are issued under \$20r(d): "The Administrator may, from time to time, issue such regulations and orders as he may deem necessary or proper in order to carry out the purposes and provisions of this Act."

¿2. "Whenever in the judgment of the Administrator such action is necessary or proper in order to effectuate the purposes of this Act, he may, by regulation or order, regulate or prohibit speculative or manipulative practices (including practices relating to changes in form or quality) or hoarding, in connection with any commodity, and speculative or manipulative practices or renting or leasing practices (including practices relating to recovery of the possession) in connection with any defense-area housing accommodations, which in his judgment are equivalent to or are likely to result in price or rent increases, as the case may be, inconsistent with the purposes of this Act." \$2(d).

${ }^{13}$ Senate Report 17: "In order to achieve effective price control it may often be necessary to regulate
} 
In establishing specifications for any commodity covered by a maximum price regulation, perfection is impossible except perhaps in the case of some basic raw materials having only a few grades. The more complicated the commodity, the more detailed the specification must be. Specification in the generic terms of everyday life, such as a "shirt" or an "ice box" is insufficient. Whether any ordinary or even extraordinary price controller can anticipate or provide detailed specifications for all possible constructions of the commodities in common use is doubtful. However, requiring that anything less than the highest grade must be sold at the price for the next grade established in the price regulation, tends to eliminate production of intermediate grades. Minute distinctions in definition can thus be avoided. The wider the gap between the top grade and the next grade adopted by the price regulation, the easier for the purchaser to appraise the commodity offered for sale in the light of the price and quality requirements, and the more effective the price control.

Discouraging the production of numerous kinds and grades not only conserves supply but is effective to prevent evasion of price control. For multiplication of types and kinds of commodities confuses the buyer so that he is unable to differentiate between the quality of the different products. This tends to render price control ineffective. ${ }^{44}$ An incidental effect of standardization and simplification will be substantial savings to the seller-savings which are likely to play an important part in the maintenance of reasonable prices to the consumer. The vital role of standardization and simplification in the price control program has not yet been generally recognized.

There are other practices which can be utilized to evade price regulation while complying with the price and quality regulations. For example, requiring combination purchases, unnecessary multiplication of middlemen, and unreasonable trade allowances all result in the consumer spending more to obtain the desired article. Special regulations under Section 2 (d) and provisions in price regulations under Section $2(\mathrm{~g})$ will be effective to regulate or prohibit such practices. ${ }^{45}$

While not producing any specific additional return for the sale of a commodity under price regulation, certain speculative and hoarding practices produce an unnecessary and unhealthy strain on the limited supply of goods available for civilian consumption, and hence threaten price increases in commodities not under control and put artificial burdens on the enforcement of existing maximum price regulations. Section 2(d) permits OPA to regulate or restrict such activities as forward buying (indicated, for example, by comparison of purchases to current deliveries) based on expected price rises, which tends to exaggerate the demand side of the supply-demand equation, or hoarding (indicated, for example, by excessive inventories, or the relation

or prohibit practices which are equivalent to concealed price or rent increases. . . Examples of such practices in connection with a commodity include manipulation of the form or quality so that the same price is charged for an inferior or less desirable product (which amounts to a price increase). . . ."

"The maximum prices fixed for each grade must, of course, present equal attraction for the manufacturer, or production of less profitable grades ceases. To protect the consumer, the standards set must also insure a useful product.

${ }^{45}$ The Senate Report refers expressly to these three practices at p. 17 . 
between the rate of acceptance of new orders and current deliveries) which artificially diminishes the supply available to meet present demands. Control of these unnecessary shortage situations is essential. It can be accomplished by preventing unjustifiable accumulations of commodities. Section $4(d)^{46}$ only prohibits OPA from requiring sales of stocks already on hand.

The statute is careful to see that these broad powers over industry practices shall be used only for price control purposes. Section $2(h)^{47}$ protects industry against requirements as to changes in established business practices, cost practices, or means or aids to distribution "except to prevent circumvention or evasion" of OPA action "under this Act." 48

\section{Agrucultural Commodities}

No provision of the Emergency Price Control Act of 1942 provoked more bitter controversy than Section 3 relating to agricultural commodities. This was inevitable. With approximately 50 million people living on farms and 130 million people in the United States dependent on agricultural commodities for their food, clothing, and thousands of indispensable derivative commodities and by-products, the stakes to the farmer, to the consumer, and, above all, to the war effort and the nation, were incalculable. The fact that the farmers are well organized ensured a thorough hearing for the farm viewpoint in the legislature and throughout the country. Fairly to resolve the conflicting interests without sacrifice to the overwhelming public interest

40 "Nothing in this Act shall be construed to require any person to sell any commodity or to offer any accommodations for rent." $\S_{4}(d)$.

"7 "The powers granted in this section shall not be used or made to operate to compel changes in the business practices, cost practices or methods, or means or aids to distribution, established in any industry, except to prevent circumvention or evasion of any regulation, order, price schedule, or requirement under this Act." \$2(h).

${ }^{8}$ This provision was inserted by the House Committee, H. R. 5990, 77th Cong., Ist Sess. (194I), $\$ 2(\mathrm{~g})$, eliminated by the Senate Committee as unnecessary, H. R. 5990, 77th Cong., 2d Sess. (Jan. 2, 1942), and restored on the floor of the Senate, H. R. 5990, 77th Cong., 2d Sess. (Jan. 12, I942), \$2(h). Originally aimed at protecting advertising, House Report 7 , the present broader language (the Senate Committee rejected a substitute section limited to advertising-see statement by Senator Taft, 88 Cong. Rec., Jan. 8, I942, at I05) does not interfere with OPA regulations necessary to prevent evasion of the price control program. Senator Vandenberg pointed out the narrow effect of subsection $(h)$ in the Senate debate on the bill: "The exemption of which I speak does not apply if the Administrator finds that these practices are being used to circumvent or evade any ceiling established in the bill. In other words, there is an cffort to draw a distinct line between a traditional, standard, appropriate, habitual business practice and one which might be invoked for the purpose of trying to evade this new control." Id. at Io8.

Senator Taft added: "Let me add, also, that I do not think the provision would prevent the Administrator from ruling out a practice adopted by a particular firm even if it had indulged in it before. It says: 'Practices ... established in any industry.'

"I should think the provision probably applied only to an industry-wide practice which the Administrator could not change."

Hoarding, speculative forward buying, and manipulations of form and quality are certainly not established in any industry.

Section 2 (e) restricts the Administrator from prohibiting trading under the Commodity Exchange Act in agricultural commodities for future delivery. Senator Butler pointed out on the floor of the Senate that this provision: ". . . does not interfere with any ceilings the Price Administrator may set, nor does it take away the power of the Price Administrator to set ceilings or to make such other regulations of market practices as he finds necessary. In other words, all futures trading, supervised by the Commodity Exchange Administration, must of necessity be subject to the maximum prices published by the Administrator." 88 Cong. Rec., Jan, ro, x942, at 245. 
and necessity, called for Congressional statesmanship of the highest order. The extent to which the Congress met or failed its responsibilities has yet to be determined.40

Section 3 of the Act carves from the basic grant of power to the Administrator, a special limitation for agricultural commodities..$^{50}$ Section 3 (a) prohibits the Administrator from establishing or maintaining maximum prices for agricultural commodities below the highest of four possible prices, as determined and published by the Secretary of Agriculture: (I) II0\% of the parity price, or comparable price, for such

${ }^{49}$ Properly to evaluate the issues requires an understanding of the economic, social, and political ramifications of one of the most difficult domestic economic problems of our times. For more than 20 years, it is alleged, there has been a relative disadvantage to farmers between the prices paid by them for commodities bought and the prices received by them for commodities sold. Even prior to 1929, farm income had failed to keep pace with the increase in national income. During the peak of "boom" prosperity, farm products could be exchanged for only $90 \%$ as much of other products, on the average, as they could have been exchanged for in the period before the war. By February 1933, the exchange value of farm products for industrial goods had fallen to $50 \%$ of the pre-war average. The exchange value of such products for services such as labor, taxes, and credit was even less. Returns per acre for 1932-33 were about $60 \%$ less than in the pre-war years, while average mortgage debt per acre was nearly three times, and taxes twice, as high. EzExIEL AND BEAN, Economic BAsEs For the Agricultural ADJUSTMENT Acr (1933). Through a far-reaching, comprehensive program of agricultural legislation, the Congress has sought to restore the relative purchasing power of the farmer. See, e.g., Agricultural Adjustment Act of 1933, 48 Stat. 31, 7 U. S. C. A. \$601; Agricultural Adjustment Act of 1938, 52 StAT. 3I, 7 U. S. C. A. \$1281; Federal Crop Insurance Act of 1938, 52 STAT. 72, 7 U. S. C. A. \$1502; Soil Conservation and Domestic Allotment Act of 1935, 49 STAT. I63, I6 U. S. C. A. \$590(a); Sugar Act of 1937, 50 STAT. 903, 7 U. S. C. A. \$rior, as am'd by Pub. L. No. 386, 77th Cong., Ist Sess. (Dec. 26, 1941); Agricultural Marketing Agreement Act of 1937, 50 STAT. 248, 7 U. S. C. A. \$67x; various appropriation acts for parity payments, 53 Stat. 974 (1939); 54 Stat. 56r (r940); Pub. L. Nos. 144 and 147, 77th Cong., Ist Sess. (July $x, 194$ I).

Eo "SEC. 3. (a) No maximum price shall be established or maintained for any agricultural commodity below the highest of any of the following prices, as determined and published by the Secretary of Agriculture: (I) IIo per centum of the parity price for such commodity, adjusted by the Secretary of Agriculture for grade, location, and scasonal differentials, or, in case a comparable price has been determined for such commodity under subsection (b), rro per centum of such comparable price, adjusted in the same manner, in lieu of Iro per centum of the parity price so adjusted; (2) the market price prevailing for such commodity on October $I, 194 \mathrm{I}$; (3) the market price prevailing for such commodity on December 15, I94I; or (4) the average price for such commodity during the period July 1, I919, to June 30, I929.

"(b) For the purposes of this Act, parity prices shall be determined and published by the Secrctary of Agriculture as authorized by law. In the case of any agricultural commodity other than the basic crops corn, wheat, cotton, rice, tobacco, and peanuts, the Secretary shall determine and publish a comparable price whenever he finds, after investigation and public hearing, that the production and consumption of such commodity has so changed in extent or character since the base period as to result in a price out of line with parity prices for basic commodities.

"(c) No maximum price shall be established or maintained for any commodity processed or manufactured in whole or substantial part from any agricultural commodity below a price which will reflect to producers of such agricultural commodity a price for such agricultural commodity equal to the highest price therefor specified in subsection (a).

"(d) Nothing contained in this Act shall be construed to modify, repeal, supersede, or affect the provisions of the Agricultural Marketing Agreement Act of 1937, as amended, or to invalidate any marketing agreement, license, or order, or any provision thereof or amendment thereto, heretofore or hereafter made or issued under the provisions of such Act.

"(e) Notwithstanding any other provision of this or any other law, no action shall be taken under this Act by the Administrator or any other person with respect to any agricultural commodity without the prior approval of the Secretary of Agriculture; except that the Administrator may take such action as may be necessary under section 202 and section 205(a) and (b) to enforce compliance with any regulation, order, price schedule or other requirement with respect to an agricultural commodity which has been previously approved by the Secretary of Agriculture.

"(f) No provision of this Act or of any existing law shall be construed to authorize any action contrary to the provisions and purposes of this section." 
commodity, adjusted by the Secretary of Agriculture for grade, location, and seasonal differentials; (2) the market price prevailing for such commodity on October I, I94I; (3) the market price prevailing for such commodity on December I5, I94I; or (4) the average price for such commodity during the period July I, IgIg to June 30 , I929. Of the four statutory minima, only two (the $110 \%$ of parity provision and the Igrg-rg29 average) require special comment. ${ }^{51}$ Of the four, parity (and comparable prices where applicable) is the only variable; the others are fixed prices. Generally speaking, the parity concept seeks to return to the farmer an income on the sale of his commodities sufficient to enable him to buy the same amount of non-farm products as he was able to buy in some base period, which in most cases is the Ig09-I4 period. 52 With Government expenditures approaching 6 billion dollars a month, it may be anticipated that parity prices will gradually increase until they become the controlling standard.

Farm representatives selected $110 \%$ of parity, as distinguished from parity itself, as most likely to return to the producer a season's average of parity prices. This provision was a part of the bill from its inception and is justified by farm representatives on the ground that it provides the producers with an adequate opportunity to realize the parity goal. Agricultural prices fluctuate widely within a season, from season to season, and from year to year. It is argued that unless agricultural prices are occasionally permitted to rise above parity, the season's average would invariably be below parity. ${ }^{58}$

Of course, $110 \%$ of parity permits a substantial increase in the prevailing prices for most agricultural commodities. For example, the price of wheat on March 15 was $\$ 1.05$ per bushel; $110 \%$ of parity on that date was $\$ 1.44$. The market price of corn on March I5 was 78.4 cents per bushel; $110 \%$ of parity was $\$ 1.04$ per bushel.

${ }^{61}$ The bill as reported by the House Committee contained the Oct. I, I94I minimum. Cottonseed oil reached a peak level on that date. This was retained without change.

The Dec. 15, I94I, alternative was a part of the O'Mahoney Amendment, 88 Cong. Rec., Jan. 9, I942, at 194 , and was retained by the conferees after the Senate conferees receded with respect to the O'Mahoney Amendment. Its purpose was allegedly the protection of such crops as burley tobacco, for which no market existed on Oct. I, 194I. It incidentally provides the highest prices for beef, veal, and wool. Id., Jan. 27,1942 , at 720 .

${ }^{2}$ Parity price is defined in the Agricultural Adjustment Act of 1938, 52 STAT. 202, 7 U. S. C. A.

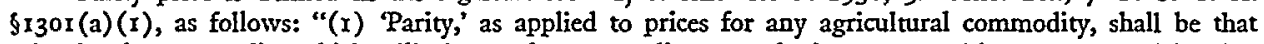
price for the commodity which will give to the commodity a purchasing power with respect to articles that farmers buy cquivalent to the purchasing power of such commodity in the base period; and, in the case of all commodities for which the base period is the period August rgog to July I914, which will also reflect current interest payments per acre on farm indebtedness secured by real estate, tax payments per acre on farm real estate, and freight rates, as contrasted with such interest payments, tax payments, and freight rates during the base period. The base period in the case of all agricultural commodities except tobacco shall be the period August 1909 to July $19 \mathrm{I}_{4}$, and, in the case of tobacco, shall be the period August Igrg to July r929."

Comparable price is nowhere defined. The concept originates in the Act of July $x, 1941$, Pub. $L$. No. 147, $77^{\text {th }}$ Cong., xst Sess., $\$_{4}(\mathrm{a})$. Comparable prices are now published for peanuts (for oil), soybeans, and peas. Midmonth Local Market Price Report, Feb. 27, 1942, p. 16.

For the best available discussion of parity, see testimony of Howard R. Tolley, Chief of the Bureau of Agricultural Economics, Department of Agriculture, before a subcommittee of the Senate Committee on Agriculture and Forestry, Hearings pursuant to $S$. Res. 177,77 th Cong., Ist Sess. (1941) pt. 2, pp. 303-374.

${ }^{\mathrm{E}}$ Senate Report 13. 
Cotton was 18.06 cents per pound on March $15 ; 110 \%$ of parity was 20.19 cents. ${ }^{54}$ As this country is called upon to satisfy an ever-increasing demand by the United Nations for foodstuffs and other agricultural products, price advances are not likely to be prevented by any excesses of supply on hand or in prospect. Because of this fact, Iro\% of parity is likely to become a formidable spiraling force, exerting upward pressure on the general level of prices.

The 19rg-rg29 average first made its appearance in the bill as reported by the House Banking and Currency Committee. ${ }^{55}$ It received immediate and widespread criticism and the Senate Banking and Currency Committee, refusing to report it, characterized it as "unreasonable and inflationary." ${ }^{66}$ To cotton it means a limitation of $2 I .47$ cents per pound. In some instances it permits returns to producers of as much as $130 \%$ of parity. Nevertheless, it has become a part of the Act. ${ }^{57}$

Section 3 (c) prohibits the Administrator from establishing or maintaining maximum prices for commodities processed or manufactured in whole or substantial part from any agricultural commodity below a price that will return to the producers of such agricultural commodities an amount equal to the highest price set forth in Section 3(a). The provision of course is not designed to prevent price action with respect to any particular derivative commodity. It is only intended to prevent the avoidance of the provisions of Section $3(\mathrm{a}){ }^{58}$ Moreover, it is the producer with whom the Congress is concerned, not the processor or manufacturer. Otherwise put, subject to the standards of Section 2(a), the Administrator may establish maximum prices with respect to those derivative commodities which for one reason or another are vital to the war effort, and withhold action from less vital commodities derived from the same agricultural commodity-so long as the particular action taken does not force the total return to producers of the agricultural commodity below the limitations of Section $3(a)$.

In appraising the breadth of the limitation imposed by Section 3 upon the Administrator's powers, ${ }^{59}$ the first inquiry must necessarily be directed to the scope of

64 Midmonth Local Market Price Report, Feb. 27, 1942. For the increase in both prices and parity since the passage of the bill, compare figures in text with those presented to the Scnate. 88 Cong. Rec., Jan. 27, I942, at 720. All of the price figures are given exclusive of Government parity, soil conservation, and other payments. In determining to what extent prices might rise before the Administrator can take action, such Government payments as are applicable should be subtracted from the figure representing $110 \%$ of parity.

${ }^{55}$ House Report 7. For a tabular presentation of the comparative effect of $\S_{3}(\mathrm{a})$, as of Dec. 15,1941 , see 88 Cong. Rec., Jan. 27, 1942, at 720.

${ }^{60}$ Senate Report 13.

67 The O'Mahoney Amendment, which would have permitted prices equivalent to $12 \mathrm{x} \%$ of parity, 88 Cong. Rec., Jan. I0, 1942, at 225, 235, was itself amended at the instance of Senator Russell to include the Igrg-rg29 average. Id. at 232. Although the Senate conferees receded from the O'Mahoney Amendment, the Conference Committee retained the 19x9-1929 average. Conference Report $21-23$.

${ }^{68}$ Senate Report 19: "Section 3 (c) and section 3 (d) insure that the powers granted to the Administrator by the bill or other powers granted under existing law, will not be so exercised as to vitiate the policy expressed in this section."

${ }^{69}$ As a part of the Conference Report rendered by Senator Brown, he said: "Some question has been raised regarding the applicability of the limitations of section 3 (a) to imported commodities. Of course, these limitations have to do only with domestic commodities, so that items such as coffee, cocoa, etc., are not subject to these limitations." 88 Cong. Rec., Jan. 27, 1942, at 724 . 
the term "agricultural commodities." Nowhere in the Act is it defined. ${ }^{60}$ Both intrinsic and extrinsic aids to construction establish that processed or manufactured commodities are not included within the term. If they were they would fall within the protection of Section 3(a), and Section 3(c) would be superfluous. As introduced in the House, the bill contained no references to processed commodities. ${ }^{61}$ Section 3(c) of H. R. 5990, as reported by the House Banking and Currency Committee, dealt with processed commodities, as did all subsequent versions of the bill. There is nothing uncertain about the purpose of the addition. It was felt that the term "agricultural commodities" did not encompass processed or manufactured commodities, and that maximum prices might be established for processed or manufactured commodities which would permit the Administrator to do by indirection what Section 3(a) prevented him from doing directly. ${ }^{62}$

The legislative history of Section 3(e), the so-called Bankhead Amendment, makes certain that processed or manufactured commodities are not included within the term "agricultural commodities." As introduced by Senator Bankhead, the amendment initially read as follows: ${ }^{68}$

Notwithstanding any other provision of law, no action shall be taken by the Administrator or any other person with respect to any agricultural commodity or commodity processed or manufactured in whole or substantial part from any agricultural commodity without the prior approval of the Secretary of Agriculture. (Italics supplied)

On January 9, Senator Bankhead modified the amendment by striking the italicized words. As so modified, after two days of stormy debate, the amendment was agreed to. ${ }^{64}$ Senator Brown, Floor Manager for the bill, stated that the modification of the Bankhead Amendment was intended greatly to reduce the number of products

${ }^{\circ 0}$ The term "commodity" is defined in $\$ 302$ (c). If this definition is equally applicable to the term "agricultural commodity," it would appear that $\$ 3$ is applicable to articles, products, materials, and services. For the reasons given in the text, it seems clear that the broad definition of "commodity" contained in $\$ 302$ (c) does not apply to the term "agricultural commodity," used in $\$ 3$.

${ }^{01}$ H. R. 5479, 77th Cong., Ist Sess. (194I).

${ }^{03}$ At p. 2073 of the House Hearings, the following exchange took place between Chairman Steagall and Secretary Wickard:

"The Chairman: Would this be true-and I am not speaking of cotton alone, but of other commodities - that it would not be necessary to fix a ceiling at parity to beat down the price of the commodity below parity, or could that be done by discriminatory ceilings placed upon the processed goods?

"Secretary Wickard: I think, of course, that you could nullify it in that way.

"The Chairman: So that, if we want to make sure that the parity provision in this bill is carried out, we will have to put some provision in the bill that will insure it?"

And see the statement of Edward O'Neal, President of the American Farm Bureau Federation, House Hearings $\mathrm{I394}$.

${ }^{03} 88$ Cong. Rec., Jan. 5, 1942, at 5; Id., Jan. 9, 1942, at 165, I77.

o Id. at 193-r94. The Bankhead Amendment is undoubtedly open to criticism as contrary to fundamental principles of good administration. Giving to the heads of two executive departments concurrent jurisdiction over the same subject matter would seem to lead only to a division of responsibility and to placing the burden of determining disputes upon an already overworked Chief Executive. The President advised the Senate of his disapproval. Id., Jan. 8, I942, at I15. Moreover, it has been forcefully argued that the Department of Agriculture is essentially a representative of the producers rather than of the consumers, and that an undesirable conflict of interest might result. As a practical matter, however, the Bankhead Amendment is perhaps no more than declaratory of the close cooperation that would inevitably have become established practice. 
which could be affected by the amendment. ${ }^{65}$ And Senator Bankhead, himself, stated that after the modification the term "agricultural commodities" was coextensive with the term as used in Section $3(a) \cdot{ }^{66}$

In the light of the Act and its legislative history, therefore, the most reasonable construction of the term "agricultural commodity," is that it is restricted to raw agricultural commodities as distinguished from processed or manufactured commodities. ${ }^{67}$

Neither Section 3(a) nor Section 3(c) indicates whether the statutory standards are inclusive or exclusive of Government payments to the producer. ${ }^{68}$ During the hearings, questions were frequently asked bearing upon the effect of price ceilings already established upon parity prices. ${ }^{60}$ Witnesses representing the Department of Agriculture, as well as farm organizations, testified upon the same subject. ${ }^{70}$ In all such discussions it was customary to include Government payments in calculating the effect of existing ceilings theretofore imposed by the Administrator, and in determining the procedure to be followed by the Administrator after the bill under consideration had become law. ${ }^{71}$

On August 13, I94I, for example, the Administrator issued Price Schedule No. I6, establishing a ceiling of $3.5^{\circ}$ cents per pound on raw sugar, duty paid New York. ${ }^{72}$ After questioning by Mr. Crawford of Michigan, as to whether such a ceiling would yield parity for the sugar beet growers, $\mathrm{Mr}$. Henderson inserted a computation in the record showing that the then parity price per ton of sugar beets was $\$ 7.15$. He pointed out that under the ceiling price, $\$ 5.30$ per ton of sugar beets would be paid

\footnotetext{
${ }^{\text {es }} 88$ Cong. Rec., Jan. 9, I942, at 177 . ${ }^{8 B}$ See note 63 , stipra.
}

or This conforms to the express statements of Senator McNary, Minority Floor Leader, and Senator Overton. 88 Cong. Rec., Jan. 9, 1942, at 177, I87. There will be close cases that may produce exceptions to the general rule. Senators Bankhead and Overton disagreed over whether butter was an agricultural commodity. Id. at I77. Gum turpentine and resin may be agricultural commodities; wood turpentine and resin are more questionable. 36 Ops. ATTY. GEN. 326 (1930); 12 U. S. C. A. \$114I(J)(g). These and other similar situations must be left for agreement between OPA and the Department of Agriculture.

${ }^{63}$ Soil conservation payments have been made with respect to cotton, corn, wheat, potatoes, pcanuts, rice, and tobacco.

Parity payments have been made with respect to cotton, corn, wheat, rice, and tobacco. In making parity payments, the Secretary has added soil conservation payments to prices reccived from the commodity, for comparative purposes with parity. Pub. L. No. I44, 77th Cong., Ist Sess. (July I, I94t), which appropriates funds for parity payments, incorporates this practice.

Conditional payments have been made with respect to sugar beets and sugar cane.

${ }^{60}$ For example, during the House Hearings, Mr. Boggs of Louisiana made the following statement: "While the Committee was in recess I checked with the Department of Agriculture figures and discovered that parity is $\$ 4.83$, and that this price of $\$ 3.50$ plus 90 cents, the Government payment, is equivalent to $\$ 4.40$, which is about to percent below parity." (Italics supplied) House Hearings 515 .

And again, at p. $937, \mathrm{Mr}$. Boggs said: "Now at a $3 \frac{1 / 2}{2}$ cent price for raw sugar, the grower receives from the processor $\$ 3.50$ per ton of sugarcane, to which must be added 90 cents conditional payment, which totals $\$ 4.40$. Four dollars and forty cents is 87 percent of the $\$ 5.03$ parity." (Italics supplied)

See also prepared statement and tabular material of Mr. Crawford of Michigan, a member of the House Banking and Currency Committee, House Hearings 724-726. The same principle is applicable equally to the other standards of $\S_{3}(\mathrm{a})$.

${ }^{70}$ Howard R. Tolley, House Hearings 2134; Dudley Smith, id. 2r42; Mr. Holman, Sec'y, National Cooperative Milk Producers Federation of Washington, D. C., Senate Hearings 363.

${ }^{71}$ See notes 69,70 , supra. And see also House Hearings 2140, 2143-44; tabular material, 88 Cong. Rec., Jan. 27, 1942, at 737.

${ }^{2} 6$ FED. REG. 4063 (I94I). 
to producers by processors. Adding the Government payment of $\$ \mathrm{r} .90$ per average ton of sugar beets to the sum of $\$ 5.30$ per ton received by the producer, would result in a total return to the producer of $\$ 7.20$ per ton. This, Mr. Henderson stated, hit parity "almost on the nose."73 The result, moreover, is obviously consistent with the recognition of farm leaders that "parity income is more important than parity unit prices."74

Another important interpretative problem is involved in the sale by the Commodity Credit Corporation of large stocks of certain agricultural commodities acquired as part of the agricultural program. ${ }^{75}$ In the normal course of events the Commodity Credit Corporation would release its stores of agricultural commodities as scarcity conditions, with accompanying inflationary prices, became imminent. Parity return to the producer would ordinarily be the Corporation's standard. This was Secretary Wickard's expressed position, at least as early as August r94I. ${ }^{\text {76 }}$

Subsequent to the passage of the Act, the Secretary gave recognition to this principle and stated that the stocks of the Commodity Credit Corporation would be sold when appropriate to prevent prices of agricultural commodities from rising above parity. It was his view that if the price of feedstuffs were allowed to rise substantially, the production of meats would diminish, and the retail price of meats produced would rise to such levels as to give further impetus to an already sharply rising cost of living. The question immediately presented was whether such sales would be inconsistent with Section 3 of the Emergency Price Control Act. ${ }^{77}$

Objective study of the Act and its legislative history leads to the conclusion that nothing in it is inconsistent with the sale of commodities by the Commodity Credit Corporation at prices below those set forth in Section 3(a). Those who hold a contrary opinion must place their principal reliance on Section $3(f)$. This section is as follows: $:^{78}$

(f) No provision of this Act or of any existing law shall be construed to authorize any action contrary to the provisions and purposes of this section.

${ }^{73}$ House Hearings 509.

14 Statement of Senator Bankhead, Senate Hearings 555.

${ }^{75}$ Commodity Credit Corporation was established in r933 under Executive Order No. 6340 and was subsequently incorporated under the laws of the State of Delaware. As of Dec. 3I, I94I, it owned substantial amounts of barley, corn, cotton, rubber, rye, tobacco, wheat, dairy products, and certain miscellaneous commodities.

70 "Secretary Wickard: Now, let me say that Commodity Credit should handle the stocks it has acquired in a way that will not beat down farm prices and income. I feel that Commodity Credit should never release its stocks for any commodity in a way that would endanger the parity objective for that commodity. But to tie up stocks in an effort to create an artificial scarcity and unreasonable prices is not in the interests of the farmer, the consumer, or the general welfare. . .

"The proposed freezing of stocks violates the principle of the ever normal granary. The theory behind the granary is that commodities will be stored up in times of surplus and released when they are needed." House Hearings 480 .

${ }^{77}$ At least some senators stated that they believed such action was contrary to $\$ 3.88$ Cong. Rec., Feb. 2, 1942 , at 939 .

${ }_{78}$ This section is identical with $\S_{3}($ d) of H. R. 5990 as reported by the House Committee. It remained unchanged thereafter. 
To begin with, this section should be contrasted with Section $2(f)$ which is directed particularly at commodities purchased and sold under the authority of Section 2(e) of the Act. Section 2(f), inter alia, is as follows:

$2(f)$... and no agricultural commodity shall be sold within the United States pursuant to the provisions of this section by any governmental agency at a price below the price limitations imposed by section 3(a) of this Act with respect to such commodity. (Italics supplied)

Clearly the Congress well knew how to restrict the sale of commodities when it saw fit to do so. Moreover, Section 2(e) expressed the plain intent to leave the Agricultural Adjustment Act of 1938 , as amended, untouched and unaffected. ${ }^{70}$

The House Conference Committee Report interprets Section $3(f)$ to contain, with respect to the sales of agricultural commodities by other governmental agencies under other provisions of law, the same limitation as Section 2(e).$^{80}$ Nothing in the legislative history of Section $3(f)$, and no intrinsic evidence in the Act, lends support to such a construction. Indeed, all of the evidence is to the contrary.

The ambiguity created by this interpretation of Section $3(f)$ was effectively put to rest by two subsequent pieces of legislative history. In delivering the Conference Report to the Senate, Senator Brown discussed the question specifically: ${ }^{81}$

... On the subject to which the Senator from Vermont (Mr. Austin) addressed himself, the issue was presented to the conferees. The question was this: Shall we prohibit existing agencies of the Government, such as the Commodity Credit Corporation, from selling agricultural commodities at prices below the price maximums fixed in Section 3 of the bill? We decided to decline to do so. We declined to permit the restriction on existing agencies. That was the amendment in which the Senator from Illinois (Mr. Lucas) was interested, and which he considered submitting to the Senate. It was pointed out that the President had vetoed a bill containing that provision, and that the Secretary of Agriculture was very much opposed to it. Therefore, so far as the general powers in the bill are concerned, we do not in any way restrict the Commodity Credit Corporation or any similar Government agency.

The language on page 2I of the House Conference report might be misconstrued if I did not make this statement. Section 3 does not in any way affect prices of commodities now in existence and owned by these agencies.

After referring to the comment in the House Conference Report, ${ }^{82}$ the report of Senator Brown continued as follows: ${ }^{83}$

${ }^{70}$ Section $2(e)$ is in part as follows: ". . . and nothing in this section, or in any existing law, shall be construed to authorize any sale or other disposition of any agricultural commodity contrary to the provisions of the Agricultural Adjustment Act of 1938, as amended. ..."

This language was contained in H. R. 5990 as reported by the Senate Committee. With respect to that language, that Committee said, Senate Report II: "The bill expressly provides that the policy laid down by the Congress with respect to agricultural commodities remains paramount to any authority conferred by the Emergency Price Control Act of 1942. The committee bill does not and cannot be construed to limit, expand, or later the existing powers and policies of the agencies charged with the administration of the Agricultural Adjustment Act of 1938 , as amended. They remain exactly as presently constituted."

${ }^{80}$ House Report 20-2z.

8188 Cong. Rec., Jan. 27, 1942, at 721. Under Senate Rules, no conference report is printed. The oral report of the floor manager constitutes the conference report to that body.

82 Supra note 80 .

${ }^{83} 88$ Cong. Rec., Jan. 27, 1942, at 722. The statement of Senator Brown on this subject is extensive and well worth close study. Id. at 72r-722. 
I desire to point out to the Senate that this inadvertent statement is not to be taken as a correct interpretation of Section $3(f)$ of the Conference agreement.

At the time of the approval of the Emergency Price Control Act by the President, the following pertinent comment was included in his general statement: ${ }^{84}$

In giving my approval to this legislation, I am acting with the understanding, confirmed by congressional leaders, that there is nothing contained therein which can be construed as a limitation upon the existing powers of governmental agencies, such as the Commodity Credit Corporation, to make sales of agricultural commodities in the normal conduct of their operations.

\section{The Power to Buy and Sell}

The power to buy and sell conferred by the Act is important because it gives the Government unquestioned control over the use of the goods purchased, and enables the Government to maintain and increase supply without penalizing the consumer. Indeed, experience under the executive orders demonstrated that, if price stability is to be achieved, in many cases the Office of Price Administration or some other agency ${ }^{85}$ must have power to buy commodities above established maximum prices and sell them below those prices. ${ }^{86}$ If ceilings are set at levels so high as to permit profitable operations by high cost producers-if, in other words, maximum prices are geared to inefficient producers-two pernicious results will follow: there will be enormous profits for the average and low cost producers; and the general price structure will

84 And see two bills introduced since the Act's passage: S. 2255, introduced on Feb. 9, by Senator Bankhead of Alabama for himself and Senators Thomas of Oklahoma, Gillette of Iowa, and Russell of Georgia, would limit the Commodity Credit Corporation to making sales or "other dispositions" not below a parity price, including transfers to other government agencies. This bill has been favorably reported, SEN. REP. No. 1054, 77th Cong., 2d Sess. (1942) with minor changes, by the Senate Committee on Agriculture and Forestry, and passed by the Senate on Feb. 25, I942. 88 Cong. Rec., Feb. 25, 1942, at 1673. On Feb. 9, 1942, Senator Nye of North Dakota introduced S. J. Res. 132, forbidding any federal agency to "perform any function" in order to prevent, or having the effect of preventing, the price of any agricultural commodity from reaching a $110 \%$ of parity price.

The Department of Agriculture appropriations bill, fiscal year 1943, H. R. 6709 (passed by the House on March 13, I942) prohibits the use of funds "for administrative expenses connected with the sale of government-owned or government-controlled stocks of farm commodities at less than parity prices" with certain exceptions regarding the use of deteriorated grain. The bill is now pending before the Senate Appropriations Committee.

${ }^{85}$ The power to sell government property, real or personal, must be specifically granted by the Congress. U. S. Const., Art. IV, \$3; Ashwander v. Tennessee Valley Authority, 297 U. S. 288 (I936); U. S. v. Nicoll, 27 Fed. Cas. No. 15,879 (C. C. D. N. Y. 1826); Wisconsin R. R. v. Price County, 133 U. S. 496 (I890); Ex parte Milligan, 4 Wall. 2 (U. S. 1866); 31 Ops. ATty. Gen. 463 (Igrg); 33 id. 570 (I923); 34 id. 320 (I924). Because of this fact, and because of the limitations on the powers of existing agencies to buy and sell, as to the commodities with which they could deal, the purposes for which they could sell, or the administrative practice, the only practicable solution was to place the power in the Administrator.

${ }^{80}$ Precedents for coupling the power to buy and sell with price control can be found in practically every country which has undertaken to check inflation. Britain has sought to stabilize the cost of living by buying the entire supply of many imported items and distributing them at a loss. See Earley and Lacy, British Wartime Control of Prices, infra. The British, furthermore, have entered into long term contracts for the purchase of metals and other materials in the Dominions and Colonies. In this arrangement the producer gains by the elimination of market risks and the Government gains by the low price which it can obtain on long term contracts. Canada has bought the entire supply of a number of shortage items and is selling them in such a way as to prevent the skyrocketing of prices which might otherwise occur. Mr. Herbert Hoover's experience as Food Administrator during the World War likewise justifies the reasonableness and effectiveness of buying and selling as a supplement to direct price control. 
be raised to inflationary levels. Yet if maximum prices are established below such levels, and no other steps are taken, needed marginal production will be lost. ${ }^{87} \mathrm{Im}$ ported commodities also present a variety of problems, more or less peculiar to those commodities, which make stabilization through ordinary price ceilings virtually impossible. ${ }^{88}$

Section 2(e) was designed to meet these difficulties. The House of Representatives originally declined to give the Administrator any power whatsoever ${ }^{80}$ and, indeed, declined to confer any additional power to buy and sell upon any existing agency. ${ }^{80}$ The Senate reinstated a broad power to buy and sell to prevent inflationary price increases, ${ }^{91}$ but the Conference Committee rewrote the provision, giving the Administrator power to buy and sell domestic or imported commodities, and to make subsidy payments, subject to the following limitations: ${ }^{22}$

(I) The power can be exercised only after a determination by the Administrator that the maximum necessary production is not being obtained or may not be obtained during the ensuing year;

(2) Any commodity which has been or hereafter may be defined as strategic or critical by the President pursuant to Section 5 d of the Reconstruction Finance Corporation $\mathrm{Act}^{93}$ may be bought or sold only by corporations created or organized pursuant to that section (the Administrator may, however, make recommendations concerning such buying and selling) $;^{04}$

${ }^{87}$ A suggested alternative to such "bulk line" price control-it was so designated during the World War-is differential pricing. This means the establishment of maximum prices for particular producers, or groups of producers, related to the individual producer's cost. Widespread use of this method would hopelessly disrupt the competitive relationship among consumers of the product. One consumcr might be fortunate enough to obtain low cost output while his competitor could only buy from a high cost producer. By the time the prices of secondary products became adjusted to such cost relationships, the results might be even more inflationary than the "bulk line" system itself.

88 "Sellers abroad are obviously not subject to price regulation by this country and prices of imported commodities will frequently reach inflated levels before the commodity becomes subject to our jurisdiction." Senate Report II. Rewards for violations of ceiling prices are tremendous when shortages of shipping or blockades reduce supply to a mere fraction of demand. The temptation to profiteer can be effectively eliminated only by permitting the Government to control the supply and arrange for its distribution to ultimate consumers at reasonable prices. Moreover, where there is a domestic as well as a foreign source of supply, power to buy and sell precludes the unwarranted enrichment of importers when the domestic price is increasing as a result of increasing costs of production in this country.

${ }^{89}$ H. R. 5990, 77th Cong., Ist Sess. (194I), passed by the House of Representatives Nov. 28, 194r, merely authorized the Administrator to notify the President, who could then direct any existing agency to exercise its existing powers to buy or sell commodities.

${ }^{90}$ See Senate Hearings I06, II2-II4.

o1 $\$ 2(e)$, H. R. 5990, 77th Cong., rst Sess. (194r), as amended by the Senate and passed Jan. 10, 1942.

$92 \$_{2}(\mathrm{e})$, Pub. L. No. 42I, 77th Cong., 2d Sess. (Jan. 30, x942). In addition to the limitations set forth in the text, two further limitations appear: ( $I$ ) Nothing in the section may be construed to affect the provisions of the Tariff Act of 1930, as amended; and (2) the Administrator may not prohibit trading in any agricultural commodity for future delivery if such trading is subject to the provisions of the Commodity Exchange Act, as amended. The former originated in the House, the latter, in the Senate.

${ }^{03}$ Act of June xo, 1941, Pub. L. No. 108, 77th Cong., ist Sess., amends $\$ 5 d$ of the Reconstruction Finance Corporation Act.

${ }^{84}$ This limitation originated in the House after strenuous objection was raised that duplication of effort would result if the Administrator were given coordinate power with RFC. It may be noted that, pursuant to the amendment of the RFC Act, Pub. L. No. 108, supra note 93, corporations may be organized by RFC with power "(a) to produce, acquire, carry, sell, or otherwise deal in strategic and critical matcrials as defined by the President; ... (g) to take such other action as the President and the Federal Loan 
(3) Commodities which are domestically produced may be imported only to the extent that the Administrator determines domestic production to be inadequate; $;^{95}$ and

(4) No agricultural commodity may be sold or otherwise disposed of contrary to the provisions of the Agricultural Adjustment Act of 1938 , as amended. ${ }^{96}$

Although the Act, generally speaking, authorizes the establishment of maximum prices, the power in the Administrator to "make subsidy payments to domestic producers ... in such amounts and in such manner and upon such terms and conditions as he determines to be necessary to obtain the maximum necessary production ....," may in some cases be used to establish minimum prices. It may also be used to relieve undue hardship which may be involved in the application of any general or special price ceiling to particular producers whose output is needed in the war program. But all power in the Administrator under Section 2(e) may be dissolved with respect to any given commodity if the President defines such commodity as strategic or critical. In that event, the power to buy and sell or to make subsidy payments vests exclusively in RFC corporations. ${ }^{97}$

Section 2(e) further provides (and this is perhaps as important as the Administrator's power) that sales made by RFC corporations shall comply with established maximums, but may be made at prices below the prices paid. This provision was inserted because the Reconstruction Finance Corporation was reluctant to admit a power to dispose of any commodity below cost. Since one of the primary objectives of the Administrator was adequate authority in the Government to subsidize marginal production, ${ }^{98}$ and to use the added output without inflating the price structure, this Congressional mandate should prove to be of value in furthering the purposes of the Act. It is, therefore, quite clear that the law does not prohibit RFC corporations, or the Administrator, from selling at a loss.

Although RFC corporations and perhaps other government agencies may be of substantial aid, the proper functioning of Section 2(e) plainly depends upon the appropriation by the Congress of sufficient funds with which to operate. Whether the Congress will effectively implement the section by reasonable appropriations remains to be seen. ${ }^{99}$ If funds are not forthcoming, the difficulties of the Administrator will surely be enhanced, and the success of the price control program may even be jeopardized.

Administrator may deem necessary to expedite the national defense program, . . ." Subsequent to passage of that act the corporate charters of Defense Supplies Corporation and Metals Reserve Company were amended to include the broad powers referred to in subsection $(\mathrm{g})$.

${ }^{O 5}$ This limitation resulted from arguments that the Administrator would be empowered, if he so chose, to flood domestic markets with imported commodities to the detriment of domestic producers.

${ }^{\circ 0}$ See also $\$ 2$ (f) which provides that no agricultural commodities may be sold pursuant to this section at a price below the price limitations with respect to agricultural commodities.

${ }^{\circ}$ Senate Hearings Ir2-114. As of Jan. 27, 1942, 105 commodities had been designated as strategic or critical.

${ }^{08}$ House Hearings 387, 401-403, 652-653; House Report 6; 87 Cong. Rec., Nov. 24, 194x, at 9309; id., Nov. 26, 194x, at 9412-9415; id., Nov. 28, 194x, at 9436-9439; Senate Hearings ro6-1 6 .

${ }^{00} \mathrm{~A}$ provision that the proceeds of any sale should be used as a revolving fund for carrying out the purposes of the section was deleted in conference, so that new appropriations must be sought as the fund is depleted. 


\section{Price Fixing, Industry Action, and the Anttrrust Laws}

A good price controller should not only have before him all of the important facts about any prices he finds it necessary to regulate, but he must also be able to persuade the sellers, or most of them, that what he has done or proposes to do, under all the circumstances, is necessary and fair. The Act, therefore, provides that the Administrator shall, so far as practicable, consult with industry members before issuing any permanent price regulation or order, and shall, if requested by a substantial part of the industry, appoint and consult with industry advisory committees. ${ }^{100}$ Experience has likewise demonstrated that during the early stages of a general price rise, when shortages are not yet acute, voluntary agreements to stabilize prices in the more concentrated and profitable industries will often suffice for a time to check speculative or unjustified increases. The Act, therefore, expressly sanctions such agreements. ${ }^{101}$

These provisions serve largely to codify the administrative practice of the Office of Price Administration as it existed prior to the statute. But industry members were quick to express their concern regarding the applicability of the antitrust laws to this type of government-industry cooperation. By his letter to Leon Henderson of April 29, I94r, Attorney General Robert H. Jackson laid down a working rule under which industry meetings, industry committee action, and voluntary agreements, requested by the Office of Price Administration, would "not be viewed by the Department of Justice as constituting a violation of the antitrust laws."102 This was not a decision to suspend antitrust enforcement, but rather a declaration that such action was not subject to the prohibitions of the antitrust laws. Under the Act, the guarantee of immunity from prosecution acquires a legislative basis. Section 205 (d) provides that persons acting in good faith pursuant to the Act, or pursuant to any requirement or agreement thereunder, shall not be "held liable for damages or penalties" in any

100 "Before issuing any regulation or order under the foregoing provisions of this subsection, the Administrator shall, so far as practicable, advise and consult with representative members of the industry which will be affected by such regulation or order. In the case of any commodity for which a maximum price has been established, the Administrator shall, at the request of any substantial portion of the industry subject to such maximum price, regulation, or order of the Administrator, appoint an industry advisory committee, or committees, either national or regional or both, consisting of such number of representatives of the industry as may be necessary in order to constitute a committee truly representative of the industry, or of the industry in such region, as the case may be. The committee shall select a chairman from among its members, and shall meet at the call of the chairman. The Administrator shall from time to time, at the request of the committee, advise and consult with the committee with respect to the regulation or order, and with respect to the form thereof, and classifications, differentiations, and adjustments therein. The committee may make such recommendations to the Administrator as it deems advisable." \$2(a).

101 "SEc. 5. In carrying out the provisions of this Act, the Administrator is authorized to confer with producers, processors, manufacturers, retailers, wholesalers, and other groups having to do with commodities, and with representatives and associations thereof, to cooperate with any agency or person, and to enter into voluntary arrangements or agreements with any such persons, groups, or associations relating to the fixing of maximum prices, the issuance of other zegulations or orders, or the other purposes of this Act, but no such arrangement or agreement shall modify any regulation, order, or price schedule previously issued which is effective in accordance with the provisions of section 2 or section 206 . The Attorncy General shall be promptly furnished with a copy of each such arrangement or agrcement."

${ }^{102}$ The procedure for clearance of antitust matters with the Department of Justice is set forth in OPA, Office Order No. 5, Oct. 15, 1941; that for clearance with the Federal Trade Commission in OPA, Office Order No. 9, Nov. 26, 1941 . 
court. $^{103}$ The word "damages" protects against civil proceedings under the antitrust laws; "penalties" protects against criminal actions for fine or imprisonment. Civil proceedings by the Department of Justice to enjoin the continuation of certain acts, or by the Federal Trade Commission to cease and desist from certain practices, are probably still available, since such proceedings look toward neither "damages" nor "penalties."104

This legislative technique of exemption from antitrust liability without direct amendment of the antitrust laws has precedents in the Lever Food and Fuel Control Act, ${ }^{105}$ the Transportation Act of $1920,{ }^{106}$ the National Industrial Recovery Act, ${ }^{107}$ and the Agricultural Adjustment Act. ${ }^{108}$ While Section 205(d) does not in terms mention the antitrust laws, the general exemption seems sufficiently broad.

There can of course be no doubt that the Congress, which has given the antitrust laws, may take them away. The Supreme Court in United States v. Socony-Vacuum Oil Co., ${ }^{109}$ while upholding a conviction for an antitrust law violation, expressly recognized that the defendants would have secured immunity had they complied with the appropriate provisions of the National Industrial Recovery Act. Accordingly, industry action which complies with the Emergency Price Control Act may safely be undertaken.

At the risk of arguing a case which Section 205 (d) makes academic, it is submitted that industry action, requested by the Administrator, would be lawful even in the absence of Section 205 (d). The sort of industry action which the Act envisages consists, mainly, of price stabilizing agreements between industry members and the Administrator, in the work of committees formed for this and other statutory purposes, and in conferences with the Administrator upon such matters. The necessity and economic soundness of such action, under the compulsion of war, probably in itself purges those acts of any illegality. But the analysis goes further.

Despite the stigma attached to the term "price-fixing," industry agreements under

103 "No person shall be held liable for damages or penalties in any Federal, State, or Territorial court, on any grounds for or in respect of anything done or omitted to be done in good faith pursuant to any provision of this Act or any regulation, order, price schedule, requirement, or agrcement thereunder, or under any price schedule of the Administrator of the Office of Price Administration or of the Administrator of the Office of Price Administration and Civilian Supply, notwithstanding that subsequently such provision, regulation, order, price schedule, requirement, or agreement may be modified, rescinded, or determined to be invalid." $\$ 205(d)$.

${ }^{104}$ The Attorney General's letter of April 29, x941, reserves to the Department of Justice "complete freedom to institute civil action to enjoin the continuation of acts or practices found not to be in the public interest and persisted in after notice to desist."

The letter is quoted extensively in Hamilton, Utilization of the Sherman Act and the Price Emergency, infra. ED.

${ }^{105}$ Act of Aug. 10, I917, 40 Stat. 276, as construed in 3r Ops. Atry. Gen. 376 (I9I9).

${ }^{10 n} \$_{407}(8), 4$ I STAT. 482, 49 U. S. C. $\$ 5(15)$, exempting from the Sherman Act carriers consolidated pursuant to an I. C. C. order.

${ }^{107}{ }_{4} 8$ STAT. 198 (1933), I5 U. S. C. $\$ 705$, providing that any code approved by the President "shall be exempt from the provisions of the antitrust laws of the United States."

${ }^{108} \$ 8(\mathrm{~b}), 4^{8}$ STAT. 34 (1933), 7 U. S. C. A. $\$ 608$ (b), allowing the Secretary of Agriculture to enter into marketing agreements, and providing that: "The making of any such agreement shall not be held to be in violation of any of the antitrust laws of the United States, and any such agreement shall be deemed to be lawful."

${ }^{100} 310$ U. S. $150,226-227$ (1940). 
authorized Government direction to set maximum rather than minimum prices are not necessarily invalid. Decisions interdicting the establishment of price floors by private agreement are commonplace. ${ }^{110}$ Yet wooden application of the price-fixing ban to the setting of maximum prices would overlook the obvious fact that such price ceilings, far from raising prices to the consumer, prevent the unlimited increase of prices and allow price competition below the levels set. ${ }^{111}$

Probably because most peace-time price agreements of businessmen have raised prices rather than lowered them, little case-law exists on the validity of action directed at imposing a price maximum. Delaware, Lackawanna \& Western R. R. v. Kutter is perhaps the most pertinent decision. ${ }^{112}$ There a private milk carrier contracted with a railroad that if the railroad would carry his milk he would charge his customers "rates not in excess of those charged by competitive railways for similar services," and would pay the railroad $80 \%$ of his gross receipts for the transportation. The railroad repudiated the contract, and in an action brought by the milk carrier set up the defense that the contract violated the Sherman Act as restraining trade. The circuit court of appeals, in awarding judgment to the milk carrier, rejected the railroad's contention: ${ }^{113}$

The provision that [the milk carrier] will charge for the transportation of milk rates not in excess of those charged by competitive railroads for similar services suggests that he is to be permitted to fix the rates subject to that restriction. If he could fix the rates solely as his own interests might dictate, it would be open to him to make rates prejudicial to the traffic or to particular shippers. But the limitation itself provides an ample protection against such an abuse of his authority, as no shipper would have just cause to complain unless his rates were in excess of the common standard for similar services....

The contract ... can only operate in restraint of trade by permitting [the milk carrier] to charge such extortionate rates to milk shippers as would discourage shippers; and this it did not permit or contemplate.

The court's view that an agreement for maximum rates is outside the Sherman Act, as protecting rather than harming the consumer, is relevant here.

Similarly, an agreement during an emergency to outlaw a speculative practice such as hoarding need not run afoul of the Sherman Act. In Fosburgh v. California

${ }^{110}$ U. S. v. Socony-Vacuum Oil Co., 310 U. S. 150 (1940); U. S. v. Trenton Potteries Co., 273 U. S. 392 (1927).

${ }^{112}$ Certain types of maximum price-setting by industry unquestionably do transgress the antitrust laws. Combinations which seek to eliminate competition by predatory cutting of prices below the costs of production have several times been invalidated under the antitrust laws. U. S. v. American Tobacco Co., 22I U. S. 106, 160, x82 (1911); U. S. v. Corn Products Refining Co., 234 Fed. 964, 989, 1013 (S. D. N. Y. 1916); cf. U. S. v. U. S. Steel Corp., 25 I U. S. 417, 440-44I (1920); U. S. v. International Harvester Co., 274 U. S. 693,708 (1927).

Again, depressing prices by a combination of btyyers rather than sellers has been held illegal. Swift \& Co. v. U. S., I96 U. S. 375 (1905). But the agreements likely to be sponsored under the Act are those of sellers.

Cases holding illegal predatory price ceilings, or the establishment of price ceilings by buycrs, may account for the occasional dictum that "depressing" prices is an illegal act. See, e.g., U. S. v. SoconyVacuum Co., stupa note 110, at 223: "Under the Sherman Act a combination formed for the purpose and with the effect of raising, depressing, fixing, pegging, or stabilizing the price of a commodity, in interstate or foreign commerce is illegal per se."

${ }^{112} 147$ Fed. 51 (C. C. A. 2d, 1906). $\quad{ }^{213}$ Id. at 6x, 63. 
and Hawaiian Sugar Refining Co. ${ }^{114}$ the defendant sugar company contracted with the plaintiff candy company to supply it with $125^{\circ}$ tons of sugar, with the proviso that

... buyer agrees to use these sugars only for his own manufacturing needs and under no circumstances to resell same.

The candy company brought suit to have the contract set aside as in violation of the Sherman Act because of this clause. A decree dismissing the complaint was affirmed upon appeal. The court said: ${ }^{115}$

In a sense, the agreement, considered in the abstract, is not without a tendency to restrict the absolutely free movement of sugar in ordinary trade relations. ... .

... while it was true that free competition, as it respects the sugar commodity in the market, was somewhat interfered with, who can say that the policy ... pursued by the Department of Justice, and, at its suggestion, conformed to by the defendant sugar company in entering into the contracts in question, was one which was prejudicial to the public interests, in that it unduly restricted competition, or unduly obstructed the course of trade?

The economic device used in the Fosburgh case is a practical method of allocation which prevents hoarding of the sugar supply by eliminating the middleman.

If these ends-the setting of price ceilings and the prevention of speculative and manipulative practices-do not run afoul of the antitrust laws, surely means ordinarily used to put them into effect enjoy equal validity. Thus, under the trade association cases in the Supreme Court sanctioning industry meetings for the discussion of lawful ends, ${ }^{116}$ the Administrator may form industry committees, and confer with those committees and individual industry members (whether pursuant to Section 2(a) or Section 5) provided the ends sought are authorized by the law.

Nevertheless, the existence of a good case for the validity of industry action even in the absence of Section 205(d) does not mean that the section serves no useful function. There are some who for their own purposes are seeking to have the antitrust laws shelved at least for the duration. Opposition to such efforts should not obscure the fact that, when businessmen are asked by the Government to undertake voluntary action, they have a right to some assurance of an immunity which will be available without the necessity of fighting for it in court, even upon the basis of sound principles. ${ }^{117}$ Section 205 (d) provides that assurance.

More significant, however, than the contemporary impact of the antitrust laws, are the issues slowly being focused by an irresistible drive for increased production. In the rationalization of production and concentration of industry likely to be re-

$$
114291 \text { Fed. } 29 \text { (C. C. A. 9th, 1923). } \quad{ }^{115} \text { Id. at } 34,35 .
$$

${ }^{110}$ Maple Flooring Mfrs. Ass'n v. U. S., 268 U. S. 563, 578 (I925); Cement Mfrs. Protective Ass'n v. U. S., 268 U. S. 588 (1925); cf. Sugar Institute, Inc. v. U. S., 297 U. S. 553 (1936).

${ }^{118}$ On March 28, I942, the President announced an agreement between the Attorney General and the Secretary of War and the Secretary of the Navy for the examination of pending and future antitrust proceedings and for the deferment of those which would "seriously interfere with the war effort." See N. Y. Times, March 29, I942, p. 33.

For extended quotations from the letters embodying this agreement, see Hamilton, Utilization of the Sherman Act and the Price Emergency, infra. Ev. 
quired by the war production program, and valid under the antitrust laws, and in the necessarily widening sphere of government ownership of war production facilities, are the seeds of perhaps the most critical post-war problem of domestic economic policy.

\section{Prohibitions}

Section 4(a) of the Emergency Price Control Act specifies the unlawful conduct against which the civil and penal sanctions of Section 205 of the Act may be directed. In general, the section parallels those provisions which authorize the Administrator to issue maximum price and other regulations, to secure information and to require licenses, and makes unlawful the violation of any such regulation, order, or requirement. ${ }^{118}$

The basic prohibition against violation of ceiling prices is applicable not only to sellers, but may be extended by the Administrator to those buyers who buy or receive price-controlled commodities "in the course of trade or business." Since time immemorial buyers and sellers have conspired to avoid regulation by the price controller. And OPA's pre-statutory experience unfortunately furnishes no evidence of the development in this country of any exception to the ordinary rule. The moral resistance of American industrial buyers to violation of law is undoubtedly strong, but not yet quite strong enough to survive the temptation of current deliveries in a short market. ${ }^{118}$

Subsection (a) also provides expressly that the prohibition against receipt of an unlawful price is not limited by any pre-existing contract, agreement, or other obligation. This provision, in one form or another, was included in every draft of the price control bill. That the Administrator must have the power to cut across existing contracts is beyond question. If his authority were confined to future sales, maximum price regulations would be ineffective to the extent that forward delivery contracts were employed in the marketing of the particular commodity. And if sellers knew that future price regulations could not affect existing commitments, they could obtain practical immunity from anticipated future regulations by contracting for the sale of their entire output or stock. Moreover, in the tight markets which presently prevail, sellers might, by the threat of refusing to sell after the establishment of maximum prices, force the acceptance of long term contracts at exorbitant prices. Speculative contracting would become widespread. And every entry by the Administrator into a

\footnotetext{
118 "SEC. 4. (a) It shall be unlawful, regardless of any contract, agreement, lease, or other obligation heretofore or hereafter entered into, for any person to sell or deliver any commodity, or in the course of trade or business to buy or receive any commodity, or to demand or receive any rent for any defense-area housing accommodations, or otherwise to do or omit to do any act, in violation of any rcgulation or order under section 2, or of any price schedule effective in accordance with the provisions of section 206, or of any regulation, order, or requirement under section 202 (b) or section 205 (f), or to offer, solicit, attempt, or agree to do any of the foregoing."

${ }^{110}$ Such pressure from buyers can be most effective when the prospective purchaser is engaged in trade or business and is either a regular customer of the seller or is equipped to make so large a purchase at the unlawful price as to offer an incentive to unlawful conduct by the seller. Persons purchasing for immediate consumption, such as housewives, are not ordinarily in a position to exert this kind of pressure upon their suppliers, and are most likely to become unwitting violators. The prohibition, accordingly, does not run against them.
} 
new commodity field would be accompanied by a flurry of price increases and futures contracting in related fields. In effect, a multi-price system would result in all regulated industries.

Moreover, if the price-fixed product were employed in the manufacture of other goods the ineffectiveness and inequity of price control which ignored existing contracts would be aggravated. Not only would it be difficult to control the prices of products resulting from such manufacture, but competitive conditions in the markets for these products would be disrupted. Manufacturers bound by contracts for supplies and materials at prices higher than the established maximums would be at an obvious disadvantage in relation to those producers who could obtain the advantage of lower prices resulting from the price controls:

Nor is there any present doubt that maximum price regulations, otherwise valid and constitutional, can properly be applied in such manner as to cut across prior contractual commitments. The Gold Clause Cases contain perhaps the most convincing single statement by the Supreme Court that Congressional power is not restricted by existing private agreements: $:^{120}$

Contracts, however express, cannot fetter the constitutional authority of the Congress. Contracts may create rights of property, but, when contracts deal with a subject matter which lies within the control of the Congress, they have a congenital infirmity. Parties cannot remove their transactions from the reach of dominant constitutional power by making contracts about them.

The immunity provisions of Section 205 (d) are clearly an adequate defense in any suit by the seller against the buyer for failure to pay a contract price which has been rendered illegal. ${ }^{121}$ May the buyer, however, insist upon his contract by offering the lawful price? The answer is likely to depend upon whether the contract price has been so substantially reduced that to require performance by the seller would be to insist upon a contract which the parties never made. ${ }^{122}$ The ability of the buyer to

${ }^{120}$ Norman v. B. * O. R. R., 294 U. S. $240,307-308$ (1935). The opinion of Mr. Justice Brandeis in Lynch v. U. S., 292 U. S. 571 (1933), makes it clear that the same principle is applicable when Congress chooscs to exercise one of its paramount powers, such as the war power, to cut across existing government contracts. See also Horowitz v. U. S., 267 U. S. 458 (I925).

${ }^{131}$ See note 103, supra. Whether the executive order of the President establishing a price control authority provides a similar defense is a separate question. The writer would answer that question in the affirmative. See Jersey Ice Cream Co. v. Banner Cone Co., $204 \mathrm{Ala}$. 532, 86 So. 382 (I920) (involving a World War priority order); Edward Maurer Co. v. Tubeless Tire Co., 272 Fed. 990, 992 (N. D. Ohio, I921), aff'd, 285 Fed. 713 (C. C. A. 6th, 1922); Restatement, Contracts (I932) \$458. See also an admirable article by Professor E. Merrick Dodd entitled Impossibility of Performance of Contracts due to Wartime Regulations (19I9) 32 HARv. L. REv. 789.

${ }_{122}$ The seller's excuse in this situation may be classed under either the defense of impossibility arising out of supervening legislation or the defense of frustration. See Discharge of Contract by Subsequent Impossibility (1931) I7I LAW Tmes 495, and BLAIR, ImpossibinITY DUE to WAR (1940) 7. In a case arising under a price schedule issued by OPACS while acting under executive order, Mr. Justice Schmuck held that the seller was excused from performing by reason of the price schedule. Kramer \& Uchitelle, Inc. v. Eddington Fabrics Corp., N. Y. Sup. Ct., Oct. r941.

There is small likelihood that sellers will use price regulation as a ground for wholesale termination of contracts because, being prohibited from selling at prices in excess of the established maximums, they cannot dispose of their goods more favorably to other purchasers. The Government in any event need not rely upon price to control the flow of goods. It may place compulsory orders, or requisition, allocate, or cstablish a system of priorities for, needed supplies and materials. 
terminate the contract even though the seller is willing to deliver at the established maximum price will depend upon whether the contract is regarded as destroyed by the regulation ${ }^{123}$ or as enforceable in a modified form by the seller. The latter result would prevent the buyer from using a regulation which lessens his burden as a pretext for terminating the contract.

A price regulation which cuts across existing contracts is also likely to raise questions about the treatment of existing inventories. To exempt dealer stocks from control would certainly encourage the speculative acquisition of commodities not already subject to regulation, and thereby produce unwarranted price increases. Yet if a ceiling on finished products were established below prevailing market levels, and made applicable to an existing inventory in the hands of middlemen, in some cases a loss might be required in the sale of those products. ${ }^{124}$

At the close of the last war Mr. Justice McReynolds stated that such a requirement would raise a "grave constitutional question." ${ }^{25}$ The basis for this statement is not disclosed in the Court's opinion and the Constitution does not deal with the problem expressly. But if the Constitution permits the establishment of maximum prices, it would seem questionable whether a lasting distinction could be made to depend on whether the particular commodities were on hand or merely en route.

\section{Investigations, Records, and Reports}

The effectiveness of any regulatory agency depends largely upon its power to obtain information. In no field is this more true than in price control. Maximum price regulations can be formulated intelligently only upon the basis of complete information regarding complex economic and business facts. Equally important, from the enforcement point of view, is the power to compel testimony and the production of documents and to require persons affected by maximum price and other regulations to make and keep records, to permit necessary inspections, and to file reports. ${ }^{120}$

The information gathering powers conferred upon the Administrator by the Emergency Price Control Act seems adequate to make possible intelligent price action and effective enforcement.

The basic authority is contained in Section 202(a) which authorizes the Administrator "to make such studies and investigations, and to obtain such information," as

${ }^{123}$ See Boret v. Vogelstein, 188 App. Div. 605, 177 N. Y. Supp. 402 (1919), aff'd, 230 N. Y. 573, r30 N. E. 898 (rg20).

${ }^{124}$ It is hardly probable that a maximum price regulation would cause loss in the sale of producer inventories, since it is a reasonably safe assumption that, in a rising-cost economy, goods produced prior to the issuance of a regulation were less costly to manufacture than goods produced afterwards.

${ }^{125}$ Matthew Addy Co. v. U. S., 264 U. S. 239,245 (1924). The same order of the Fuel Administrator was involved in Majestic Coal Co. v. Bush \& Co., 171 N. Y. Supp. 662 (1918), and by way of dictum the court said: "I can not find anything ... which could compel legitimate jobbers in fuel to sell coal at prices less than the purchase prices bona fide paid by said jobbers to the mines. If there were anything in them to that effect, it would be void and unconstitutional." p. 667.

${ }^{120}$ During the period of its pre-statutory activity, OPA encountered many difficulties traceable to the lack of specific investigatory authority. Persons subject to price schedules frequently prevented detection of the actual circumstances surrounding sales and other transactions by the simple device of failing to keep or destroying records. In some instances enforcement was hindered by the refusal of persons to allow the inspection of relevant documents. 
he deems necessary in prescribing any regulation or order, or in the administration and enforcement of the Act and the regulations and orders issued pursuant to its delegation of power. ${ }^{127}$ The manner in which this authority may be exercised is detailed in the succeeding subsections of Section 202. The Administrator is authorized, by regulation or order, to require any person engaged in the business of dealing with any commodity or in the rental of housing accommodations to furnish all necessary information, to make and keep records, and to make reports. Testimony and the production of documents can be compelled by administrative subpena. Whenever necessary, the Administrator may require of persons engaged in dealing with commodities or in defense housing accommodations that they permit the inspection and copying of records and other documents, the inspection of inventories, and the inspection of defense area housing accommodations. ${ }^{128}$

Section 202(d) qualifies the power of the Administrator to compel the production of a person's documents at any place other than his regular place of business. The production of documents cannot be required, if, prior to the return date specified in the subpena issued with respect to the documents, such person either has furnished the Administrator with a certified copy of the documents or has entered into a stipulation with the Administrator regarding the information contained therein. ${ }^{129}$ This is a novel provision designed to facilitate compliance by the small businessman.

Subpenas issued by the Administrator under the broad provisions of Section 202(b) of the Act are self-executing and may be enforced directly by the civil and criminal sanctions of Section 205 of the Act: the general prohibitions section, Section 4 (a), expressly makes it unlawful "to do or omit to do any act in violation of any ... order or requirement under Section 202(b)." Other subpenas issued by the Administrator $^{130}$ are enforceable only by application to the district court for an order requiring obedience to the subpena. Subpenas issued under Section 202(b) may also be enforced in this way. ${ }^{131}$

127 "The Administrator is authorized to make such studies and investigations and to obtain such information as he deems necessary or proper to assist him in prescribing any regulation or order under this Act, or in the administration and enforcement of this Act and regulations, orders, and price schedules thereunder." $\$ 202(a)$.

12S "The Administrator is further authorized, by regulation or order, to require any person who is cngaged in the business of dealing with any commodity, or who rents or offers for rent or acts as broker or agent for the rental of any housing accommodations, to furnish any such information under oath or affirmation or otherwise, to make and keep records and other documents, and to make reports, and he may require any such person to permit the inspection and copying of records and other documents, the inspection of inventories, and the inspection of defense-area housing accommodations. The Administrator may administer oaths and affirmations and may, whenever necessary, by subpena require any such person to appear and testify or to appear and produce documents, or both, at any designated place." \$202(b).

120 "The production of a person's documents at any place other than his place of business shall not be required under this section in any case in which, prior to the return date specified in the subpena issued with respect thereto, such person either has furnished the Administrator with a copy of such documents (ccrtified by such person under oath to be a true and correct copy), or has entered into a stipulation with the Administrator as to the information contained in such documents." \$202(d).

130 "For the purpose of obtaining any information under subsection (a), the Administrator may by subpena require any other person to appear and testify or to appear and produce documents, or both, at any designated place." \$202(c).

${ }_{101}$ The summary nature of proceedings to enforce subpenas under $\$ 202(\mathrm{e})$ is established by decisions under other comparable statutes. Since an investigation is a preparatory matter looking to the enforcement 
Section $202(\mathrm{~g})$ of the Act provides that no person shall be excused from complying with any investigatory requirement of the Administrator because of his privilege against self-incrimination, but that the immunity provisions of the Compulsory Testimony Act of February II, I893 ${ }^{132}$ shall apply with respect to any individual who specifically claims his privilege. The requirement that such immunity must specifically be claimed ${ }^{133}$ serves to put the Administrator on notice that immunity might result from the testimony or use of documents with respect to which the immunity is granted. Thus the Administrator is given an opportunity to determine whether it is more advantageous to compel the testimony and thereby make available to the witness whatever immunity may result, or to forego the evidence and retain the right to subject such person to whatever criminal and other sanctions may be available under the Act. ${ }^{134}$

Unjustified disclosure of confidential information is forbidden by Section 202(h) of the Act. ${ }^{135}$ This provision, buttressed by Section 4 (c) (which makes it unlawful for any OPA employee to disclose or use such information otherwise than in the

of the Act and makes no determination between the parties, In re Securities and Exchange Commission, 84 F. (2d) 3r6, 317 (C. C. A. 2d, I936), rev'd as moot, 299 U. S. 504 (1936), a proceeding to enforce an administrative subpena is not a "civil action" but is a summary proceeding of a special nature. In re Securities \& Exchange Commission, supra; Goodyear Tire \& Rubber Co. v. N. L. R. B., I22 F. (2d) 450 (C. C. A. 6th, 194I); Fleming v. Montgomery Ward \& Co., Ir4 F. (2d) 384 (C. C. A. 7th, r940), cert. denied, 3 II U. S. 690 (I940). The Federal Rules of Civil Procedure do not apply to such proceedings. Goodyear Tire \& Rubber Co. v. N. L. R. B., supra; Cudahy Packing Co. v. N. L. R. B., II7 F. (2d) 692 (C. C. A. roth, r94r).

${ }^{132} 27$ Stat. 443 (1893), 49 U. S. C. $\$ 46$. This statute, so far as material, provides: "But no person shall be prosecuted or subjected to any penalty or forfeiture for or on account of any transaction, matter or thing, concerning which he may testify, or produce evidence, documentary or otherwise, before said commission, or in obedience to its subpena, or the subpena of either of them, or in any such case or proceeding; Provided, That no person so testifying shall be exempt from prosecution and punishment for perjury committed in so testifying."

${ }_{133}$ Under immunity statutes failing to require a specific claim of privilege against self-incrimination as a condition of obtaining immunity, some courts have held that such a claim is not a condition to obtaining immunity. U. S. v. Goldman, 28 F. (2d) 424 (D. Conn. 1928); U. S. v. Pardue, 294 Fcd. 543 (S. D. Tex. 1923); U. S. v. Armour, 142 Fed. 808 (N. D. Ill. 1906). But most courts hold that even under such statutes a claim of privilege is necessary. U. S. v. Lee, 290 Fed. 517 (N. D. Tex. I923), aff d, 297 Fed. 704 (C. C. A. 5th, r924), sub nom. Sherwin v. U. S., af'd, 268 U. S. 369 (1925); U. S. v. Lay Fish Co., ${ }_{3}$ F. (2d) 136 (S. D. N. Y. 1926); U. S. v. Elton, 222 Fed. 428 (S. D. N. Y. 1915). The constitutional privilege against self-incrimination is waived by failure to claim the privilege before testifying. U. S. v. Murdock, 284 U. S. I4I, I48 (I93I); Brown v. Walker, I6I U. S. 59I (1896).

${ }^{134}$ It is settled law that neither a corporation, Hale v. Henkel, 20 r U. S. 43 (1906); Wilson v. U. S., 221 U. S. $36 \mathrm{r}$ (Igrr), nor a corporate officer, Grant v. U. S., 227 U. S. 74 (19r3); Whecler v. U. S., 226 U. $S$. 478 (1913), can claim any privilege against self-incrimination because of the production of corporate records. No immunity results, therefore, from the compulsory production of corporate records. This exception arises from the fact that corporate records "are held subject to examination by the demanding authority." Wilson v. U. S., supra at 382 . On the same principle, records required by law to be kept are beyond operation of the privilege against self-incrimination and the corresponding immunity. Spring Drug Co. v. U. S., I2 F. (2d) 852 (C. C. A. 8th, I926); U. S. v. Sherry, 294 Fed. 684 (N. D. Ill. 1923); U. S. v. Mulligan, 268 Fed. 893 (N. D. N. Y. I920). In U. S. v. Mulligan, stupra, it was held that the privilege against self-incrimination did not extend to the records of an individual which were required to be kept under the authority of the Lever Act.

135 "The Administrator shall not publish or disclose any information obtained under this Act that such Administrator deems confidential or with reference to which a request for confidential treatment is made by the person furnishing such information, unless he determines that the withholding thereof is contrary to the interest of the national defense and security." \$202(h). 
course of official duty), should protect essential business secrets and should assure the requisite full disclosure of essential business facts to the Office of Price Administration.

\section{ENFORCEMENT}

The Administrator is armed by the Emergency Price Control Act with a complement of enforcement tools which is in marked contrast to the circumscribed and unwieldy sanctions which were available to secure observance of price schedules issued during the pre-statutory period..$^{130}$ The statutory catalog includes the civil injunction, the criminal penalty, the treble damage suit, and the license.

Section 205(a) of the Act authorizes the Administrator to apply for injunctive relief whenever any person has engaged or is about to engage in any acts or practices prohibited by Section $4 \cdot{ }^{137}$ Equitable proceedings to enjoin violations of the Act, or to secure an order enforcing compliance may be brought by the Administrator either in the federal district courts or in the courts of any State or Territory. ${ }^{138}$ OPA attorneys may appear for and represent the Administrator in these proceedings and in any other proceeding which the Administrator is authorized to bring. The Act provides that a permanent or temporary injunction, restraining order, or other necessary order shall be granted upon a showing by the Administrator to the Court that the defendant has engaged or is about to engage in any unlawful acts or practices. Neither the validity of the Act nor the validity of the regulation which has been violated is involved in any such proceeding.

Section 205 (b) of the Act states that any person who willfully violates any provision of Section 4, or who willfully falsifies any document or report required by the Act, shall be subject to a fine of not more than $\$ 5,000$, or to imprisonment for not more than one year, or both. Whenever the Administrator has reason to believe that any person has violated the criminal provisions of the Act, he may certify the facts to the Attorney General, who may, in his discretion, bring an appropriate criminal proceeding in the proper federal district court.

A third sanction which may afford some incentive to general public participation in the compliance program is provided by Section 205(e). Any person who buys

${ }^{136}$ Despite handicaps resulting from enforcement sanctions which were of necessity ill-suited to particular case treatment, $60 \%$ of the pre-statutory cases in which violations were established after compliance conferences terminated in agreements to makc full restitution and to abide by the price schedules in the future. In $12 \%$ of the cases violations of a minor character were established and letters of warning sent to the persons involved. The remainder of the cases either concerned consumers, against whom as a class effective sanctions were peculiarly difficult to operate, or are yet pending.

107 "Whenever in the judgment of the Administrator any person has engaged or is about to engage in any acts or practices which constitute or will constitute a violation of any provision of section 4 of this Act, he may make application to the appropriate court for an order enjoining such acts or practices, or for an order enforcing compliance with such provision, and upon a showing by the Administrator that such person has engaged or is about to engage in any such acts or practices a permanent or temporary injunction, restraining order or other order shall be granted without bond." \$205(a).

${ }^{138}$ Criminal proceedings may be brought in any district in which any part of any act or transaction constituting the violation occurred; other proceedings may be brought not only in such district, but also in the district wherein the defendant resides or transacts business. Process may be served in any district wherein the defendant resides or transacts business or wherever the defendant may be found. $\$ 205(\mathrm{c})$. 
a commodity for use or consumption other than in the course of trade or business, or who pays rent, at a rate above that established by a maximum price or rent regulation, may bring an action either for $\$ 50$ or for three times the amount of the overcharge, plus reasonable attorney's fees and costs as determined by the court. If the purchaser in any given transaction is not entitled to bring suit, the Administrator may sue for the amount involved on behalf of the United States. Proceedings under this subsection (which does not become effective until July 30, 1942) may be brought in any court of competent jurisdiction, but must be brought within one year after delivery is completed or rent is paid. ${ }^{130}$

This provision has caused some concern on the ground that it may be abused not only by irate and uninhibited consumers and consumer groups, but by others less well intentioned. It is distinctly unpleasant in wartime to be hauled into court and charged with profiteering: a seller might well prefer to forestall the threat with a cash payment. To this criticism there are two answers. The first is that in the more blatant cases of abuse, the Administrator could intervene on behalf of the defendant and probably would. ${ }^{140}$ The second is that a wise public policy requires, when the stakes are so large and the task of enforcement may be so great, that the Administrator be allied with his most numerous beneficiaries, the consumers. Whether Section 205 (e) will in fact ease the burden of enforcement very likely depends on the extent to which the country accepts price control as vital to the war effort. Only if it becomes a patriotic duty to comply with price ceilings, and unpatriotic to bootleg goods, will Section 205 (e) be of any substantial value.

Of all the sanctions provided by the Act, however, licensing is likely to prove the most useful. In industries in which great numbers of persons are engaged, the requirement of licenses provides an excellent means of building up a register of persons subject to regulation. License suspension even for a limited period is a more flexible and less harsh procedure than criminal prosecution and, in the great majority of cases, is vastly more of a deterrent than the suit in equity to enjoin further violations.

Moreover, experience has established the effectiveness of licensing as a regulatory technique. The licensing sanction has frequently been employed in important federal

\footnotetext{
${ }^{230}$ The use of civil damage suits as an aid in the enforcement of a regulatory statute is not a new procedure. Similar provisions exist in the patent law, 35 U. S. C. $\$ 67$, in laws protecting trade marks, is U. S. C. \$96, and trade marks in the international register, 15 U. S. C. \$124. They are found in the provisions against dumping foreign commodities, 15 U. S. C. \$72, or in operating a railroad inequitably, 45 U. S. C. $\$ 83$. Well-known examples are also contained in the Sherman Anti-Trust Act, I5 U. S. C. \$15 (since this provision has been held inapplicable to the United States, U. S. v. Cooper Corp., 312 U. S. $600(\mathrm{x} 94 \mathrm{r}), \S 205$ (e) expressly provides for such suits on behalf of the United States under certain circumstances), the Wilson Tariff Act, 28 StaT. 570 (1894), and the Clayton Act, 15 U. S. C. $\$ 15$. A very recent use of this sanction is to be found in the District of Columbia Emergency Rent Act, \$10, Pub. L. No. 327, 77th Cong., 1st Sess. (Dec. 2, 194x). Statistical data regarding a similar provision in the Fair Labor Standards Act of 1938,29 U. S. C. A. $\$ 2 x 6$, illustrates its enforcement value. During the first three years of administration of that Act, approximately $85 \%$ of all enforcement procecdings, about 2815 in all, were such civil damage actions.

140 “. . . In any suit or action wherein a party relies for ground of relief or defense upon this Act or any regulation, order, price schedule, requirement, or agreement thercunder, the court having jurisdiction of such suit or action shall certify such fact to the Administrator. The Administrator may intervene in any such suit or action." $\$ 205(d)$.
} 
and state regulatory legislation. ${ }^{141}$ In Canada and in England licensing is now relied upon as the principal sanction to secure the observance of price and rationing regulations. ${ }^{142}$ In the United States during the World War, the Lever Act conferred licensing powers upon the Food Administrator, and at the end of the war 263,737 firms were under license in the Food Administration alone. In his Annual Report for I9I $7,{ }^{143}$ Food Administrator Herbert Hoover testified to the effectiveness of his licensing powers:

The licensing system, however, is the backbone of all control. Without compulsion there will always be a few slackers in every trade who will profit by the patriotism of the majority and prevent any effective control.

Indeed, the necessity of licensing as a price control sanction was demonstrated so clearly in the World War experience that President Wilson, without statutory authority, conferred licensing powers upon the Fuel Administration.

The provisions of the Act ${ }^{144}$ which confer the basic licensing authority upon the Administrator do not explain how licenses are to be issued, except to say that a separate license need not be issued for each commodity or for each maximum price regulation. As a matter of administrative efficiency, license applications will normally be required from all persons in the industry subject to licensing control, since a register of persons subject to regulation can most easily be compiled from the applications received. ${ }^{145}$ Whether actual physical documents will be sent to license applicants is likely to depend on the nature of the industry. The distribution of such licenses and a requirement of conspicuous display. would provide a simple way to determine whether a particular seller has, in fact, obtained a license. But there may be grave administrative difficulties if applications were required and licenses printed and distributed, say, in the entire retail trade. In some cases general licenses may be issued coupled with a supplementary reporting requirement. These and other matters of administrative machinery must of course be worked out in practice and by reference to the circumstances existing in particular fields of control.

The licensing powers of the Administrator are surrounded with uniquely elab-

${ }^{161}$ E.g., the "Hot Oil" Act, 15 U. S. C. A. \$715; Natural Gas Act, 15 U. S. C. A. \$717(b); Federal Fircarms Act, 15 U. S. C. A. \$\$90I-909; Federal Alcohol Administration Act, 27 U. S. C. A. 203-204(e); Federal Communications Act, 47 U. S. C. $\$ \$ 15 I, 303,309,319,402$; Motor Carrier Act, 49 U. S. C. A. $\$ \$ 301-327$; Civil Aeronautics Act, 49 U. S. C. A. $\$ \$ 40 \mathrm{r}-682$; Gold Reserve Act, $3 \mathrm{r}$ U. S. C. $\$ \$ 440-446$; Commodity Exchange Act, 7 U. S. C. A. $\$ \$ I-17$ (a); Cotton Standards Act, 7 U. S. C. A. $\$ \$ 5 x-65 ;$ Packers and Stockyards Act, 7 U. S. C. $\$ \S 8 \mathrm{I}-23 \mathrm{I}$; U. S. Warehouse Act, 7 U. S. C. $\$ \$ 24 \mathrm{I}-273$; Perishable Agricultural Commodities Act, 7 U. S. C. $\$ 499$; Tobacco Control Act, 7 U. S. C. A. $\$ \$ 515-515 k$; Securities Act, 15 U. S. C. \$77a; Securities Exchange Act, I5 U. S. C. \$78a; Public Utilities Holding Company Act, I5 U. S. C. A. \$79; Trust Indenture Act, I5 U. S. C. A. $\$ \$ 77 a a a-77 b b b b$.

${ }^{163}$ See Memorandum, "Emergency Price Control Legislation-Enforcement Provisions," Senate Hearings $18 \mathrm{r}, \mathrm{I} 86$ et seq.

${ }^{143}$ H. R. Doc. No. 837, 65th Cong., 2d Sess. (I9I7). And see ANs. Rep. U. S. Food AdM'N (I918) 16. But note Mr. Hoover's condemnation of licensing as a price control sanction before the Senate Banking and Currency Committee, Senate Hearings 416.

$14 \S_{205}(\mathrm{f})$.

215 "The licensing provision is necessary where you do not know who is doing business. It is impossible where there is a multiplicity of sellers to know to whom a regulation should be specifically addressed." Testimony of Leon Henderson, Senate Hearings 150. 
orate safeguards for the protection of private rights. No person may be refused a license, unless an order of suspension of a previous license is in effect against him. No license may contain any provision which could not be prescribed by regulation or order under Section 2 or Section 202 of the Act. The licensing provisions are so drawn as to prevent even the appearance of administrative interference with civil liberties or with the free expression of ideas. No license may be required as a condition of selling or distributing newspapers, books, motion pictures, or radio time. ${ }^{140}$

Concern for the protection of private interests against possible abuse of administrative power is particularly evident in the guarded procedure for license suspension spelled out in Section 205(f)(2) of the Act. Whenever the Administrator believes that a licensee has violated any of the provisions of his license, or of any regulation or order to which he is subject, a warning notice must be sent by registered mail. If there is reason to believe that the licensee, after receipt of warning notice, has again been guilty of a violation, the Administrator may petition for a court order suspending the license for a period of not more than 12 months.

The issue open in proceedings for license suspension is, by the terms of the Act, limited to the question whether the licensee has, in fact, violated any provision of the license, or of a regulation or order, after the receipt of the warning notice. If the court finds this to be the fact, an order is issued suspending the license to the extent that it authorizes the licensee to sell the commodity or commodities in connection with which the violation occurred, or to the extent that it authorizes the licensee to sell any commodity or commodities to which a maximum price regulation is applicable. Since the activities of but one person are involved, a stay of any order of suspension may be granted in accordance with local practice when justifying circumstances exist.

Congressional consideration for small business in distant communities is shown by the provision of Section 205 (f) (2) that proceedings for license suspension must be brought by the Administrator in the state or territorial court, unless the licensee is doing business in more than one state or unless his gross sales exceed \$roo,000 per annum. ${ }^{147}$ Section 205 (f) represents a compromise between administrative necessity and the protection of individual rights. Although proceedings for license suspension are of an equity nature, ${ }^{148}$ and so do not require jury trial of the facts, suspension

\footnotetext{
${ }^{140}$ And see the further proviso of $\$ 205(f)(x):$ ". . . no license may be required of any farmer as a condition of selling any agricultural commodity produced by him, and no license may be required of any fisherman as a condition of selling any fishery commodity caught or taken by him."

${ }^{147}$ The requirement that license suspension proceedings be brought in state courts was suggested by Senator Brown at a late stage of the hearings before the Senate Committee. Senate Hearings 550. This reference to the state courts may raise constitutional questions involving federal-state relations. However, the power of the Congress to impose jurisdiction to suspend licenses upon the state courts seems well established by decisions in which the Supreme Court has held that a state court has no discretion to rcfuse to exercise its jurisdiction in actions to enforce rights created by federal law. Second Employers' Liability Cases, 223 U. S. I, 58 (I9I2); McKnett v. St. L. \& S. F. Ry., 292 U. S. 230, 233 (1934); U. S. v. Bank of New York, 296 U. S. 463, 479 (I936). And see the discussion of federal-state relations in Opinion of the Legislative Counsel, U. S. Senate, May 26, I926, 67 Cong. Rec. 10087, ro089-ro0gr. Compare Prigg v. Pennsylvania, I6 Peters 539 (U. S. I842).

${ }^{148}$ Senate Report 27.
} 
by court order may be less speedy, in many cases, than the more usual procedure of administrative suspension with subsequent judicial review. ${ }^{149}$ The fact that suspension proceedings will often be brought in the state courts means that those charged with the administration and enforcement of the Act must take account of 48 different systems of trial and appellate practice.

At the same time, it is evident that the procedure required by the Act will provide as nearly perfect assurance against arbitrary administrative action as could reasonably have been devised. Public recognition of the fairness of the licensing provisions of the Act will greatly enlarge its usefulness.

\section{Termination Date}

A legislative compromise is reflected in Section I(b) of the Act, which provides that the authority of the Act, and all regulations or orders issued thereunder, shall terminate on June 30 , I943, or upon an earlier date specified by Presidential proclamation or by concurrent resolution of the Congress. The provision for termination by concurrent resolution, although not without precedent in recent defense legislation, ${ }^{150}$ raises serious questions. If the issue be justiciable, ${ }^{151}$ a close question of constitutionality is presented. ${ }^{162}$ In any event, one may question the political wisdom of a device which, in substantial effect, deprives the President of his constitutional prerogative to exercise a veto power over legislation.

It is certainly to be expected that the authority of the Act will be continued beyond the specified termination date, June 30, r943. Even if the war has been fought to a successful conclusion by the beginning of 1943 , which now seems realistically improbable, the inflation which followed the First World War ${ }^{153}$ stands as an urgent warning that the brakes against inflation must not be taken off before a full return to a peace-time economy has been achieved. When the war is won, the tested tools of economic direction must then be turned to the winning of the peace.

${ }^{140}$ The original price control bill, H. R. 5479, $\$ 205(\mathrm{c})$, provided for administrative suspension or revocation of licenses, subject to judicial review in the Emergency Court of Appeals. The House Committee struck the entire licensing subsection from the bill. The licensing provisions in their present form were inserted by the Senate Committee. See Senate Report 8-9, 26-28; Conference Report 26.

${ }^{160}$ For example, the powers of the President under the Lend-Lease Act, Pub. L. No. Ir, 77th Cong., Ist Sess. (March II, I94I), can be terminated by concurrent resolution declaring them no longer necessary for the defense of the United States.

${ }^{262}$ See Coleman v. Miller, 307 U. S. 433 (x939).

${ }^{162}$ Article I, Section 7, of the Constitution provides: "Every order, resolution, or vote to which the concurrence of the Senate and House of Representatives may be necessary (except on a question of adjournment) shall be presented to the President of the United States, and before the same shall take effect, shall be approved by him, or being disapproved by him, shall be repassed by two-thirds of the Senate and House of Representatives, according to the rules and limitations prescribed in the case of a bill."

The constitutionality of the concurrent resolution provision of H. R. 5479 was considered in a memorandum submitted by the writer to the House Banking and Currency Committee. House Hearings $983-985$.

163 "In I91 8 prices again started upward, reaching an index of about 200 before the end of the year. Inflation was not over, however, with the Armistice in November 19r8; in fact, the worst was yet to come. The controls were taken off too soon and the index of prices spiraled up another 40 points to 240 in 1920. From that point we had severe deflation with bankruptcy and all the losses that deflation entails." Memorandum, "The World War Inflation," House Hearings 204. 